Available online at http://dergipark.gov.tr/iujad Inonu University Journal of Art and Design

Faculty Homepage: http://www.inonu.edu.tr/tr/gsf

\title{
Öğrencilerin Selçuk Üniversitesi, Alaeddin Keykubad Kampüsü'ne Yönelik Suç Korkusu
}

\section{Fear of Crime of Students Regarding Selçuk University, Alaeddin Keykubad Campus}

\author{
Filiz ÇELİKa*日iD, Esra Mirzab@iD
}

a Doç. Dr., Selçuk Üniversitesi, Mimarlık ve Tasarım Fakültesi, Peyzaj Mimarlığı Bölümü, Konya, 42130, Türkiye b Doktora Öğrencisi, Süleyman Demirel Üniversitesi, Fen bilimleri Enstitüsü, Mimarlık Planlama ve Tasarım ABD, Isparta, 32260, Türkiye

Article history: Received 14-04-2020 / Accepted 18-11-2020

\section{ÖZET ABSTRACT}

Korku, bir tehlike veya tehlike düşüncesi, tehdit, risk, kaygı ve endişe gibi uyarıcıların etkisiyle ortaya çıkan güvensizlik algısıdır. Suc, yasalara ve kurallara aykırı davranış olarak ifade edilirken; suç korkusu, bir suçun mağduru olma korkusu şeklinde ifade edilmektedir. Bireysel ve toplumsal bir olgu olan suç korkusu, mekânsal boyutta da etkilidir. Bir mekânın güvensiz algılanmasına ve korku hissine sebep olan sorunların başında suç korkusu yer almaktadır. Kentlerin güvensiz olduğu endişesinin giderek artmasına paralel olarak suç korkusu da bütün Dünyada yaygınlaşmaktadır. Üniversite kampüsleri de tıpkı kentler gibi güvensizlik algısına bağlı olarak suç korkusunun yaşandığı mekânsa etkilere sahiptir. Suç korkusu, bir yandan güvensizlik yaratarak kampüsteki yaşamı sınırlandırmakta diğer yandan da kampüsteki düzen, huzur ortamı, yaşam kalitesi, konfor seviyesi ve sosyal kontrolü olumsuz etkilemektedir.

$\mathrm{Bu}$ çalışmanın amacl, öğrencilerin Alaeddin Keykubad Kampüsü fiziksel özelliklerine ilişkin suç korkusu algılarını belirlemektir. Nitel ve nicel sorgulama yöntemine göre elde edilen veriler doğrultusunda Alaeddin Keykubad Kampüsü'nün güvensiz algılanan ve suça maruz kalma riskinin yüksek olduğu yerler belirlenmiştir. Alaeddin Keykubad Kampüsü'nde öğrencilerin güvenlik algısına olumlu yönde katkı sağlayacak ve suça maruz kalma riskini azaltacak önerilere yer verilmiştir.

Anahtar Kelimeler: Güvenlik, Kampüs Güvenliği, Risk Algısı, Suç, Suç Korkusu.
Fear is the perception of mistrust that is caused by stimuli like danger or thought of danger, threat, risk, anxiety and worry. Crime is expressed as acting against rules and laws; while fear of crime is expressed as the fear of being the victim of a crime. Fear of crime, which is an individual and social phenomenon, is also effective on spatial plane. It is one of the problems, which cause that a place is perceived as unsafe, and ends up in fear. The perception of crime in urban areas creates the sense of insecurity. Parallel to the increasing concern that cities are unsafe, fear of crime is also spreading all over the world. Just like cities, university campuses also have spatial effects, which have fear of crime because of insecurity perception. On the one hand, fear of crime limits the life in campus by causing mistrust; on the other hand, it affects order, peace, quality of life, comfort level and social control on campus in a negative way.

The purpose of this study was to determine the perceptions of the students on fear of crime regarding the physical characteristics of Alaeddin Keykubad Campus. According to the data obtained with the qualitative and quantitative questioning method, it was determined that the places in Alaeddin Keykubad Campus were perceived as unsafe, and had high risk of being exposed to crime. In this respect, recommendations were made to contribute positively to the safety perception of students and to reduce the risk of crime in the campus.

Keywords: Security, Campus Security, Risk Perception, Crime, Fear of Crime.

\section{GİRİŞ}

Güvenlik, insan temel ihtiyaçlarından biridir ve Avrupa Kentsel Şartı'nda yer belirtildiği gibi, bir yaşam ve kentli hakkıdır. Kendini güvende hisseden birey, huzurlu ve mutlu bir şekilde yaşamını devam ettirebilir (Ataç ve Gürbüz, 2009, s.26). Güvensizlik duygusu ise bireyde kaygı, korku ve endişeye neden olurken kendini güvende hissetmeyen bireylerin oluşturduğu toplumlarda birçok sorun ortaya çıkmaktadır. Toplumsal gerilim ve baskı, öfke ve şiddete neden olmaktadır (Çelik vd, 2018, s.218). Güvenlik kaygısı yaşayan bir insanın en önemli gündemi o kaygının ortadan kalkması ve böylece normal bir yaşam sürdürebilmesidir (Kula ve Çakar, 2015, s.194).

* Corresponding Author

http://dx.doi.org/ 10.16950/iujad.720049 
Korku, bir tehlike veya tehlike düşüncesi, tehdit, risk, kaygı ve endişe gibi uyarıcıların etkisiyle ortaya çıkan güvensizlik algısıdır. Suç ise yasalara ve kurallara aykırı davranış olarak ifade edilirken suç korkusu, bir suçun mağduru olma korkusu şeklinde ifade edilmektedir. Suç korkusu, suçla çok yakından ilgili olmakla birlikte bazı durumlarda suçtan bağımsız bir olgudur. Kriminoloji literatüründe suç korkusuna ilişkin yapılan sayısız araştırma, suç oranlarındaki artışa paralel olarak artan suç korkusunun, suç oranlarındaki düşüşle birlikte düşmediğini göstermektedir. Bu nedenle suç korkusu, bazı durumlarda suçla birlikte bazı durumlarda ise suçtan bağımsız bir şekilde ele alınması gereken önemli bir problemdir (Dolu vd., 2010, s.58). Bazı durumlarda suç korkusu, suçun kendisinden daha yaygındır. Farklı suçların varlığı, farklı suç korkularının da ortaya çıkmasına neden olmaktadır (Özaşçılar ve Ziyalar, 2009, s.8).

Suçun kentsel mekandaki algısı, güvensizlik duygusu yaratmaktadır. Bireysel ve toplumsal bir olgu olan suç korkusu, mekânsal boyutta da etkilidir. Bir mekânın güvensiz algılanmasına ve korku hissine sebep olan sorunların başında suç korkusu yer almaktadır. Kentlerin güvensiz olduğu endişesinin giderek artmasına paralel olarak suç korkusu, bütün dünyada yaygınlaşmaktadır. Üniversite kampüsleri de tıpkı kentler gibi güvensizliğe bağlı olarak suç korkusunun yaşandığı mekânsal etkilere sahiptir.

Güvenliğin eksiksiz sağlandığı durumlarda bile insanlar suç mağduru olmaktan korkmakta ve evlerinde, sokaklarında, mahallelerinde, parklarda vb. yerlerde endişe ve korku içinde yaşamaktadırlar. Özellikle güvenlik hizmetinin sağlanamadığı bölgelerde "suç mağduru olma" korkusu artmaktadır. Bir suçun mağduru olmanın yarattığı genel bir duygu olarak suç korkusu toplumdaki kişilerin iyilik hali üzerinde de önemli bir etki oluşturmaktadır (Aytaç vd, 2015, s.260). Bu reaksiyonun en doğal sonucu olarak suç korkusu bireylerin günlük aktivitelerini sınırlamakta, sosyal bir izolasyon oluşturarak kişilerin yaşam kalitelerini düşürmekte ve sonuçta yaşama dair doyumsuz, huzursuz, gergin ve mutsuz bireylerin ortaya çıkmasına sebep olmaktadır (Kula ve Çakar, 2015, s.198). Suç korkusu hem bireylerin yaşam kalitesini hem de toplumu olumsuz etkileyen önemli bir sosyal sorundur. Kalabalık yerlere gitmekten çekinme, toplu taşıma araçlarını kullanmaktan ve gece taksiye binmekten kaçınma, internet hesaplarının şifrelerini sık sık değiştirme, evde kimse olmadığı durumlarda hırsızlık olasılığına karşı evin ışıklarını açık bırakma gibi davranışlar bu korkunun günlük hayattaki yansımalarıdır (Çoklar ve Solak, 2017, s.313).

Bugün Türkiye'nin de güncel kentsel sorunlarından biri olarak kent güvenliğine eşlik eden problemlerin başında suç korkusu gelmektedir. Kapkaç, gasp, hırsızlık, tecavüz, uyuşturucu kullanımı veya ticareti gibi geleneksel kentsel suçlara artan göç ve terör olaylarının neden olduğu mağduriyetler de eklemlenmiş durumdadır (Sipahi, 2017, s.385).

Bireyler içinde bulundukları her ortamda güven içinde ve suç korkusundan uzak yaşayabilmelidir. Suç korkusunun ortadan kaldırılması veya kontrol edilmesi, güvenlik algısının ve buna paralel olarak yaşam kalitesinin arttırılması bakımından büyük önem taşımaktadır. Üniversite kampüsleri de öğrenci, akademik ve idari personelin refah içinde yaşamlarını sürdürmelerini sağlayacakları suç korkusundan uzak, güvenli ortam sunmalıdır. Bu çalışmanın amacl; Alaeddin Keykubad Kampüsünde Selçuk Üniversitesi öğrencilerinin suç korkusuna yönelik algılarını belirlemektir. Bu amaçla kampüsteki suç korkusu ile güvenlik algısı arasındaki bağlantıyı ortaya koymak için kentlerle ilgili yapılmış olan araştırmalar incelenmiştir. Çalışma kapsamında elde edilen nitel ve nicel veriler doğrultusunda Alaeddin Keykubad Kampüsü'nün güvensiz ve suça maruz kalma riskinin yüksek olduğu yerleri belirlenmiş; daha güvenli ve suç korkusundan uzak bir kampüs için önerilere yer verilmiştir.

\section{GÜVENLİK ve SUÇ KORKUSU İLİŞKİSİ}

Güvenlik, bireysel ve toplumsal açıdan gerçek veya algısal olarak suç tehditlerinden uzak olmak şeklide ifade edilebilir (Anonim, 2012). Güvenlik, aynı zamanda bir duygu ve algıdır. Neyin güvenli veya güvensiz olduğu, bireye (yaş, cinsiyet), topluma, zamana, psikolojik duruma, mekâna, sosyo-ekonomik ve kültürel özelliklere göre farklılık gösterebilmektedir. Bu bağlamda nesnel olmaktan çok öznel bir durum olan güvenlik algısı değişken bir özelliğe de sahiptir. Güvenlik veya güvensizlik, bireyin içinde bulunduğu durumu algılama sonrasında korku, risk, tehdit ve tehlike kavramlarıyla birlikte ifade edilmektedir (Çelik, 2018, s.60). 
Kısaca "bir suçun mağduru olma korkusu" olarak ifade edilen suç korkusu, geniş anlamda; "bireysel ve toplumsal süreçleri kapsayan, güvensizlik duygusu ve algısı" olarak tanımlanmaktadır (Kul, 2013, s.29). Ferraro suç korkusunu, "bir suça ya da kişinin suç ile ilişkilendirdiği sembollere karşı geliştirdiği duygusal korku veya endişe reaksiyonu" olarak tanımlamaktadır (Ferraro, 1995, s.44). Warr ise algılanan çevreye karşı geliştirilen duygusal reaksiyon şeklinde tanımlamıştır (Warr, 2000, s.453). Suç korkusu, suçun toplum içinde yarattığı güvensizlik algısı olarak ifade edildiğinde güvenlik ve suç korkusu arasındaki ilişki de bariz şekilde ortaya çıkmaktadır. İnsanların kendilerini ne kadar güvende hissettiklerinin bir göstergesi olarak kabul edilen "suç korkusu seviyesi," devlet otoritesi tarafından sunulan güvenlik hizmetlerinin kalitesini ve etkinliğini belirleyecek en önemli ölçütlerden birisi sayılabilir (Dolu vd., 2010, s.61).

Literatürde suç korkusunun nedenlerini açıklamak üzere farklı teoriler öne sürülmüştür. Bu teorileri savunmasızlık teorisi, mağduriyet teorisi, düzensizlik teorisi ve toplumsal kaygı teorisi olarak sınıflandırmak mümkündür (Öztürk, 2015, s.255). Bu teoriler doğrultusunda suç korkusunun nedenleri;

- Daha önce kişinin kendisi veya yakınlarından birinin suça maruz kalması,

- Bireylerin suçla ilgili duyduğu gerçekte yaşanmış veya yaşanmış gibi anlatılan olaylar,

- Bireylerin suçla ilgili bilgi edinme kaynakları (medya, internet ve cep telefonları vb.),

- Yaş (artan yaşla birlikte suç korkusu artmaktadır),

- Cinsiyet (kadınlar, erkeklere oranla daha fazla suç korkusu taşımaktadır),

- Medeni durum,

- Ekonomik durum,

- Eğitim seviyesi (ekonomik durumu iyi olanlar ile daha eğitimli olan kişiler suçtan daha az korkmaktadır),

- Sosyal statü (sosyal statü düştükçe suç korkusu da artmaktadır),

- Aile ve komşuluk ilişkilerinin olmaması veya bozuk aile ve komşuluk ilişkileri,

- Suç ve şiddet olayları,

- Fiziki uygarlıktan uzaklaşma etkileri (mekânsal düzensizlik, dağınık ve toplanmamış çöpler, duvar yazıları, vandalizm, boş araziler, terk edilmiş binalar ve arabalar vb.),

- Sosyal uygarlıktan uzaklaşma etkileri (evsiz insanlar, dilenciler, alkolikler, madde bağımlıları, sokak çeteleri ve başıboş gençler),

- Zayıf sosyal katılım, nüfus ve yerleşim yoğunluğu, ırk-yaş-cinsiyet farklılıkları, kalabalık, yaya ve araç trafiği, binaların boyutu ve hizmet yetersizliği gibi kentsel özelliklerdir (Özaşçılar ve Ziyalar, 2009, s.8; Özaşçılar, 2015, s.333).

Risk değerlendirmesi teorisini öne süren Ferraro (1995, s.15), bireylerin risk tahmini yaparken bulundukları çevreden aldıkları bilgileri kullandığını iddia etmektedir. Buna göre bireyler, etrafında tehlike oluşturacak düzensizlikler olduğunu görürse, suça maruz kalma konusunda daha fazla kaygılanmaktadır. Yapılan bilimsel çalışmalar incelendiğinde genel anlamda, kentlerin güvensiz hale gelmesinin toplum üzerinde giderek yaygınlaşan suça maruz kalma ya da suça tanık olma gibi korkulardan kaynaklanan "güvensizlik hissi"nin oluşmasına neden olduğu da görülmektedir (Ataç, 2007, s.16). Özellikle psikolojik sağlık açısından suç korkusu, öfke, engellenme, kaygı, çaresizlik, yabancılaşma, güvensizlik ve düşük yaşam doyumu ile ilişkilendirilmektedir. Davranışsal boyutta ise suç korkusu, kişilerin kendilerini güvende hissetmedikleri yer ve aktivitelerden kaçınmalarına yol açmaktadır (Çoklar ve Solak, 2017, s.314). Suç korkusu, insanların kendilerini ne kadar güvende hissettikleri, güvenlik hizmetlerinin kalitesi ve vatandaşların bu hizmetlerden ne kadar memnun oldukları noktasında en önemli ölçütlerden biri olarak değerlendirilmelidir (Dolu vd., 2010, s.61).

Kentsel mekânda kullanıcıların birbirleriyle (sosyal çevre) ve çevresiyle (fiziksel çevre) olan ilişkilerinin mekandaki güvenlik ve suç ile doğrudan ilişkili olduğu görülmüştür. Bu da güvenli mekanlarının oluşturulmasında öncelikle o mekânda suçu oluşturan ya da suça neden olan mekânsal özelliklerin saptanması ve orada yaşayan ya da o mekânı düzenli olarak kullanan insanların yaşadıkları ve kullandıkları yeri nasıl algıladıklarının çözümlenmesi gereğini doğurmaktadır (Ataç, 2007, s.18).

Güvenlik algısı özellikle sosyal, kültürel, ekonomik ve fiziksel farklılıkların bulunduğu mekanlarda suç korkusuyla ilişkili bir duygudur. Suç ve suç korkusunun mekânı kullanan 
insanda oluşturduğu algı güvensizlik hissidir. Ayrıca fiziksel ve sosyal düzensizlik insanlarda güvensizlik algısı yaratarak suç korkusunu ortaya çıkarmaktadır. Fiziksel bir çevrenin düzensiz hale gelmesi insanlar üzerinde suç korkusundan kaynaklanan güvensizlik hissinin oluşmasına neden olmaktadır. Bir suçun mağduru olma ve güvensizlik algısının neden olduğu suç korkusu, insanların yaşamını hem zorlaştırmakta hem de yaşam kalitesini düşürmektedir.

Bireylerde suç korkusunun ortaya çıkışı toplumdaki suç aktivitesinin yüksekliği veya bireylerin bu aktiviteleri duymasıyla ilişkilendirilmektedir. Korku, suçun algılanmasıyla gerçekleşirken suç mağduru olan bireyler suçtan korkmaya daha yatkındır. Bireyler doğrudan bir suçun mağduru olmasalar da suç faaliyetini gözlemleyerek veya sosyal çevreleri aracılığıyla maruz kalarak suç korkusu geliştirebilirler. Bu konuda medya da suç korkusunun topluma yayılmasında önemli bir rol oynamaktadır (Karakaya, 2015, s.16).

\section{3. ÜNİVERSİTE KAMPÜSLERİNDE SUÇ KORKUSU}

Genel olarak, üniversite kampüslerinin güvenli olduğu düşünülse de araştırma sonuçları, öğrencilerin suç korkusu yaşadıklarını göstermektedir. Üniversite kampüslerinde güvenlik önlemleri alınmasına ve mevcut önlemlerin iyileştirilmesine rağmen, üniversitelerdeki öğrenciler suç korkusu taşımaktadır. Kampüsteki öğrencilerin, mağduriyet ihtimaline ilişkin risk algıları ve kampüs içinde meydana gelen suç olayları, suç korkusuyla birlikte koruyucu davranışlarda bulunma ve kaçınma davranışlarını şekillendirmektedir (White, 2019, s.7).

Suç korkusu ile ilgili yapılan araştırmalar, kişisel özelliklerin ve bağlamsal faktörlerin suç korkusuyla anlamlı bir şekilde ilişkili olduğunu göstermektedir. Diğer demografik gruplarla karşılaştırıldığında, yaşlılar, azınlıklar ve kadınlar arasında daha yüksek düzeyde suç korkusu olduğu görülmektedir. Kampüs ve suç korkusu arasındaki ilişkiye yönelik yapılan çalışmalarda ise daha genç öğrenciler, kadınlar ve azınlıklar arasında korku düzeyinin daha yüksek olduğu, özellikle kız öğrencilerin daha yüksek düzeyde suç korkusu ve suç mağduru olma korkusu yaşadıklarını, kampüste mağduriyet risklerini azaltmak için erkek öğrencilere göre daha fazla davranışlarını kısıtladıkları ortaya koyulmuştur (Kaminski vd., 2010, s.89).

Yapılan çalışmalar, öğrencilerin suç korkusunda gece ya da gündüz olması ve kampüsteki belirli alanlar arasında ilişki olduğunu ortaya koymuştur. Del Carmen vd. (2000)'nin yaptığı çalışmada, öğrencilerin $\% 68^{\prime i}$ gece, gündüze göre suç mağduru olmaktan daha çok korktuklarını ifade etmiştir. McConnell (1997) ise yaptığı çalışmada katılımcıların yalnızca $\% 20$ 'sinin gündüz kampüste yalnız yürümekten korktuğunu, \%66'sının ise gece kampüste yalnız yürümekten korktuğunu ortaya koymuştur. Brantingham ve Brantingham'ın 1994 yılında yaptığı çalışmada ankete katılan öğrencilerin gündüz \%98'inin kampüste güvenli hissettiğini, gece ise öğrencilerin \%33'ünün güvensiz hissettiği sonucuna ulaşmıştır. Elde ettiği sonuçları cinsiyete göre değerlendirdiğinde ise erkeklerin \%88'i kampüste gündüz güvenli hissederken; gece için bu oran \%52'ye düşmüştür (Kaminski vd., 2010, s.89).

\subsection{Suç Korkusu Algısında Kampüsün Fiziksel Çevresinin Etkisi}

Strange ve Banning'e (2001) göre üniversite kampüsleri öğrencilere fiziksel çevre, birikim çevresi, organize çevre ve sosyal çevre olmak üzere dört farklı çevre sunmaktadır. Bunlar arasında en öne çıkan fiziksel çevre, kampüsün doğal ve yapay bileşenlerini içermektedir. Fiziksel çevre, idari birimler, eğitim-öğretim binaları, öğrenci yurtları, lojmanlar, misafirhane, konferans salonu, açık ve kapalı spor alanları, dini yapı, sağlık tesisi, yeme-içme ve alış-veriş mekanları, ulaşım ağı, otoparklar ve yeşil alanlar gibi sosyal donatılardan oluşmaktadır. Güvenlik ve suç korkusu algısı, kampüsteki sosyal çevre ve fiziksel çevreye bağlıdır. Güvensizliğe neden olan suçun, fiziksel çevreyle doğrudan ilişkili olduğu bilinmekte ve suç korkusu fiziksel çevrenin özelliklerinden kaynaklanabilmektedir (Çelik vd. 2018, s.219)

Araştırmalar, üniversite kampüslerindeki suç korkusunun fiziksel çevrenin farklı özelliklerinden kaynaklanabileceğini ortaya koymaktadır. Kampüsün tasarım özellikleri ve fiziksel düzeniyle ilişkili olarak suça ve bireysel güvenlik kaygılarına neden olması, genç ve savunmasız öğrencilerin suç ve bireysel güvenlik sorunlarını yaşamasına neden olmaktadır. Aydınlatma düzeyi, peyzaj, güvenlik ekipmanları, kampüs çevresi ve kampüsün açık erişim felsefesi, öğrencilerin bireysel güvenliğini etkileyen konulardır (Waters, Neale and Mears, 2005, s.231). 
Kampüste suç korkusu, kampüsün mimarisine ve peyzaj tasarımına göre değişmekte ve bu önemli bir faktör olarak karşımıza çıkmaktadır. Yapılan çalışmalar, öğrencilerin kampüste bir suçun kurbanı olmaktan korktuğu için bazı alanları kullanmaktan kaçındığını göstermektedir.

Fiziksel çevre yoluyla iletilen sözel olmayan mesajlar arasında güvenlik ve suç korkusu algısı da bulunmaktadır. Üniversite kampüslerindeki fiziki çevre, öğrencilere üniversite deneyimi ile ilgili sözel olmayan, sembolik mesajlar iletmekte ve sosyal etkileşimlere zemin oluşturmaktadır (Strange ve Banning, 2001, s.5). Öğrencilere yönelik pek çok sözel olmayan mesajlar, kampüsteki bina tasarımlarından, açık-yeşil alanlardan, tabelalardan, patikalardan, heykellerden, yaya ve araç trafiğinin akışını şekillendiren unsurlar ile peyzaj düzenlemelerinden gelmektedir (Schuetz, 2005, s.67).

Kampüste suç korkusu, ırk, yaş, cinsiyet gibi demografik özellikler ya da kampüsün fiziksel çevre özelliklerinden kaynaklanan faktörler arasındaki farklılıklar nedeniyle karmaşık bir konudur. McCreedy ve Dennis (1996, s.77)'in yaptıkları çalışmaya göre ankete katılan öğrencilerin yaklaşık \%86'sı şiddet mağduru olma konusunda yüksek düzeyde endişe duyduklarını bildirmiştir. Daha spesifik olarak, cinsel taciz ve saldırı gibi durumlar karşısında duyulan suç korkusu \%95'e yükselmiştir. McCreedy ve Dennis'e göre, bireysel suç mağdurları için bu yüksek rakamlar, gerçekte veya öğrencilerin algısına göre, kampüsün güvenli bir ortam olmadığını düşündürmektedir. Jennings ve arkadaşları (2007) öğrencilerin suç mağduriyeti olasılığını azaltmak amacıyla davranışlarını kısıtladıklarını; algılanan korku, güvenlik, risk ve kısıtlı davranışlar geliştirmede cinsiyet farklılıkları olduğunu ortaya koymuştur. Archer (2014)'in çalışmasında öğrencilere, kampüs güvenliği ile ilgili olarak kampüste genel güvenlik, gece boyunca kampüsteki güvenlik ve üniversitenin yeterli güvenlik önlemi alıp almadığı ile ilgili anket uygulanmış; kampüsteki öğrencilerin gündüze nazaran geceleri daha fazla suç korkusu hissettiklerini ve ayrıca kampüste kadınların geceleri erkeklere göre kendilerini daha az güvende hissettiklerini belirlemiştir. Brantingham and Brantingham (1994)'ın çalışma sonucuna göre kampüse kendi arabalarıyla gelen öğrenciler, toplu taşıma araçlarını kullanan öğrencilere göre gece kampüsü daha güvensiz bulmaktadır.

\subsection{Kampüste Güvenlik ve Suç Korkusu İçin Alınacak Önlemler}

Kampüste güvenlik ve suç korkusu için yapılacak çalışmalar ve alınabilecek önlemler, üç ana başlıkta toplanabilir:

- Yükseköğretim Kurulu, üniversite yönetimi ve kampüs güvenlik biriminin çalışmaları,

- Fiziksel çevre için kampüste peyzaj tasarımı ile önlemler geliştirme,

- Sosyal çevre için kampüste peyzaj tasarımı ile davranışsal önlemler alınmasıdır.

\subsubsection{Yükseköğretim Kurulu, Üniversite Yönetimi ve Kampüs Güvenlik Biriminin Çalışmaları}

Yapılan çalışmalar, birçok öğrencinin kampüste "güvensiz" ya da "korku" hissettiğini, özellikle kadınların gece kampüs ve çevresinde suçla ilgili endişelendiğini göstermektedir. Araştırmalara göre bu korkular yersiz değildir ve her üçöğrenciden birinin kampüs yaşamı sırasında herhangi bir kampüs suçunun kurbanı olabileceği ve tüm kampüs suçlarının \%80'inin öğrenciler tarafından işlendiği tahmin edilmektedir (Fisher, 1995, s.99).

Kampüste suç, öğrencilerin hayatlarını etkileyen günlük bir olaydır. Son yıllarda üniversite kampüslerinde öğrenci sayısında büyük artış yaşanmış ve kampüs suçlarının da buna paralel bir şekilde arttığı görülmüştür. Kampüs, kamuya açık olması nedeniyle geniş bir topluluğun paydasıdır ve bu durum kampüste suçun önlemesinde yaşanan bir zorluk olarak ortaya çıkmaktadır. Çok fazla sayıda öğrenci, çalışan ve ziyaretçiyi durdurmak ya da üstünü aramak mümkün olmamaktadır. Kampüsteki tüm hareketler kontrol edilememekte bu durum kampüsü savunmasız bir hale getirmektedir (Woolnough, 2009, s.41). Bunların sonucu olarak kampüsteki suç korkusu ve suç mağduriyetine karşı üniversite yönetimleri tarafından birtakım hukuki ve yönetimsel önlemler geliştirilmiştir (Bedenbaugh, 2013, s.13).

Kampüs Güvenlik Yasası (Clery Yasası), Amerika'da kolej ve üniversitelerin kampüs ve yakınlarında gerçekleşen suç ve güvenlik olaylarını kamuoyuyla paylaşmasını zorunlu kılan federal bir yasadır. Bu yasa, mevcut ve gelecekteki öğrencileri ile çalışanlarını bilgilendirme amacıyla kampüs suç istatistikleri ve güvenlik politikaları yayınlamaları için yükseköğretim 
kurumlarına sorumluluk vermektedir. Clery Yasası, öğrencileri, ebeveynleri ve çalışanları kampüsteki suçlar hakkında bilgilendirerek kendi güvenlikleri hakkında bilinçli seçimler yapmalarını sağlayacak bir tüketici koruma yasası olarak kabul edilmiştir (Fisher, 1995, s.91).

1990 yılında yürürlüğe girmiş olan yasa, 1986 'da Jeanne Clery isimli üniversite öğrencisinin üniversite yurdunda öldürülmesiyle gelişen olaylara dayanmaktadır. Lehigh Üniversitesi, Hukuk öğrencisi Jeanne Clery, kaldığı yurdun güvenlik önlemleri olmasına rağmen güvenlik açığından faydalanarak yurda hırsızlık için giren bir öğrenci tarafından darp edilir ve öldürülür. O yıllarda üniversitelerin bunun gibi olayları kamuoyuna bildirme yükümlülüğü olmadığı için bu olay fazla ses getirmez. Ancak ebeveynleri, hukuki süreç başlatarak kampüsü olan kolej ve üniversitelerin suç olaylarını kamuoyuyla paylaşmalarını sağlayacak yasal düzenleme yapılmasını talep etmiştir. 1990 yılında yayınlanan "Kampüs Güvenlik Yasası" (The Campus Security Act of 1990) ve ardından 1998 yılında gelen "Kampüs Suçu Bilgilendirme Yasası" (The Campus Crime Disclosure Act of 1998 daha sonra Clery Act of 2000 olarak yeniden adlandırılmıştır) ve 2008 yılındaki "Jeanne Clery Yasası Değiş̧iklikleri" kampüs suçlarının raporlanmasını, bir suç işlendiğinde öğrencilerin bilgilendirilmesini ve kampüs güvenliği raporlarının kamuya açık bir şekilde bildirilmesini zorunlu kılmıştır. Amaç öğrencilere kampüsteki suç seviyeleri hakkında bilgi vermek, öğrencilerin kampüs güvenliği konusundaki endişeleri üzerinde durmak ve duyarlı olmaktır (Woolnough, 2009, s.41). İlk başlarda yalnızca \%4'ü bu bilgiyi yayınlarken günümüzde 6.000 'in üzerinde lise sonrası eğitim kurumu yıllık olarak suç istatistiklerini paylaşmakta ve ABD Eğitim Bakanlığı da denetlemektedir. Aynı zamanda "Kampüs Güvenliği ve Emniyeti" web sitesi, suç istatistikleri ve diğer ilgili bilgilerin kapsamlı bir veri tabanına erişim sağlamaktadır (URL-1, 2019).

Üniversite yönetimleri suç mağduriyeti ve olasılıkları azaltmak için kampüsün fiziksel ortamını, özellikle de işaret ve aydınlatma ile hedef alan önlemler de geliştirmişlerdir. Kampüste fiziksel bir değişiklik yapabilmek için kampüs güvenlik denetimi ve suç etkisi beyanı yapmalarını istemektedir. Rochester Üniversitesi'nde suç önleme ofisi, inşaat ve tadilat işleriyle ilgilenmektedir. Kör noktalar, karanlık koridorlar, yetersiz aydınlatma, uygun olmayan çevre ve otopark düzenlemesi, yaya yolu tasarımı gibi bireysel güvenliği içeren konularda planları gözden geçirmekte ve veri girişi gerçekleştirmektedir. Bu ofis aynı zamanda aydınlatma ve peyzaj tasarımında standartlar için saha incelemeleri de yapmaktadır (Fisher, 1995, s.99).

Türkiye'de ise üniversitelerde rektörlüğe bağlı Genel Sekreter birimi altında Koruma ve Güvenlik Müdürlüğü veya Koruma ve Güvenlik Şube Müdürlüğü, görev, yetki ve sorumlulukların tanımlandığı Güvenlik Yönergesi doğrultusunda faaliyet göstermektedir. 2547 sayılı Yükseköğretim Kanunu ve 5188 sayılı Özel Güvenlik Hizmetlerine Dair Kanun ve Yönetmeliğe dayanarak üniversite kampüslerinde açık ve kapalı mekanlarda koruma ve güvenliğin sağlanması ile suçun önlenmesi yönünde uygulamalar yapılmaktadır.

Yükseköğretim Kurulu (YÖK), son dönemlerde üniversitelerde akademisyenlerin maruz kaldığı ve bazılarının ölümle sonuçlandığı şiddet olaylarına karşı araştırma başlatmıştır. Üniversitelerdeki şiddet olaylarının nedenlerini araştırmak ve tedbirler almak için "Üniversitelerde Huzur ve Güveni Artırma Komisyonu" kurulmuş ve geçici ortak komisyonun ilk toplantısı 15 Ocak 2019 tarihinde "Üniversitelerde Huzuru ve Güveni Artırma Toplantısı" adı altında gerçekleştirilmiştir. Akademik ve idari personel ile öğrencilerin, huzur ve güven içinde eğitim-öğretim, araştırma ve geliştirme ile topluma hizmet misyonlarını gerçekleştirmeyi teminen "Üniversitelerde Huzur ve Güveni Artırma Komisyonu", ilgili YÖK Yürütme Kurulu Üyeleri, İçişleri Bakanlığı, İller idaresi Genel Müdürlüğü, Emniyet Genel Müdürlüğü ve Jandarma Genel Komutanlığı'ndan üst düzey yetkililerin yanı sıra üniversitelerde ilgili alanlarda uzman olan akademisyenlerin katılımıyla YÖK Başkanı başkanlığında toplanarak öncelikle:

- Huzur ve güveni artırmak için, devlet ve vakıf üniversitelerinde, kampüslere yönelik güvenlik verilerinin toplanması ve risk analizinin yapılması,

- Üniversitelere ait kampüslerin girişinde özel güvenlik görevlileri tarafından yapılan önleyici güvenlik tedbirlerinin artırılması,

- Fiziki tedbirlere yardımcı olan araç ve gereçlerin nicel ve niteliğinin artırılması,

- Üniversitelerde şiddet ve huzursuzluğa sebep olan nedenlere ilişkin bilimsel çalışmaların başlatılmasının teşvik edilmesi yönünde kararlar alınmıştır (URL-2, 2019). 


\subsubsection{Fiziksel Çevre İçin Kampüste Peyzaj Tasarımı ile Önlemler Geliştirme}

Güvenlik ve suç korkusu ile ilgili tasarıma yönelik kriterler, suç önleme konusunda yapılan araştırmalardan ve kullanıcıların dış mekân özelliklerine yönelik psikolojik tepkilerinden geliştirilmiştir. Suçun, mekân eksenli stratejilerle önlenebileceğine ilişkin ilk mimari yaklaşım, 1972 yılında yayınladığı "Savunulabilir Alan: Kentsel Tasarım Yoluyla Suçun Önlenmesi" (Defensible Space: Crime Prevention Through Urban Design) isimli kitabıyla Oscar Newman tarafından geliştirilmiştir. Oscar Newman, savunulabilir alan veya savunulabilir mekân teorisi ile başarılı kentsel alanların mevcut koşullarını inceleyen ve onları istenmeyen yerlerle karşılaştıran yeni teoriler sunmuştur. Suç ve mekân ilişkisinden yola çıkarak geliştirilen savunulabilir mekân teorisi, insanın içinde bulunduğu mekânın suçu teşvik etme veya engelleme niteliğinde olduğu tezine dayanmaktadır (Newman, 1973).

Newman bir kentsel mekânın fiziksel özelliklerinin, o mekânda yaşayan ya da o mekânı sürekli olarak kullanan kişilerle, potansiyel suçluların sosyal davranışlarını doğrudan etkilediğini ileri sürmüş ve mekânda uygulanacak fiziksel müdahalelerin bu durumu olumlu yönde değiştirebileceğini savunmuştur. Dolayısıyla Newman'a göre, kentsel mekâna yapılacak fiziksel müdahale ile oradaki sosyal yaşamı kuvvetlendirmek, suça yönelik izlemeleri kolaylaştırmak ve mekânın doğal yollarla kendini suça karşı koruyabilmesini sağlamak mümkündür. Savunulabilir mekân, 4 tasarım unsuruna göre oluşturulabilir. Bunlar, bölgesellik, doğal gözetim, çevresel görünüm ve çevre/muhitten oluşan savunulabilirliktir (Çelik, 2018, s.75).

Durumsal Suç Önleme Teorisi ise suç fırsatlarını azaltarak suçun, suçlular açısından karlı bir tercih olmaktan çıkarılabileceği ve böylece suçun önlenebileceği felsefesine dayanmaktadır. Suç işlenme olasılığı olan yerlerde alınacak önlemlerle, uygulanacak tekniklerle, yapılacak fiziki düzenlemelerle ve çevresel tasarımlarla suçla ilgili fırsatların ve suçu cazip hale getirici unsurların azaltılabileceği savunulmaktadır. Teoriye göre, çevrede yapılacak düzenlemeler, potansiyel suçluların yapacağı kar ve zarar analizini etkileyebilecek düzeyde olmalı, yani işlenecek suçun maliyeti faydasından daha çok olmalıdır. Durumsal suç önleme teorisinin temelleri, "rutin aktiviteler teorisi" ve "rasyonel tercih teorisi"ne dayanmaktadır. Bu teorilerden farklı olarak durumsal suç önleme teorisi, içinde bulunduğu koşulların elverişliliğine bağlı olarak tüm insanların suç işleme olasılığının bulunduğunu ileri sürmektedir. Diğer bir deyişle, suç işleme olasılığı açısından suçlular ve diğer insanlar arasında bir ayrım yapmamaktadır (Clarke, 1995, s.91; Clarke, 1997, s.4). Bu teori, hedef olarak seçilmesi muhtemel mal ve şahısları korumak amacıyla kullanılabileceği gibi olası suçları önlemek için suç mahallerinde de kullanılabilir. Örneğin, suç işlenme olasıı̆ı̆ olan binaların camlarına demir parmaklıklar takılması, güvenlik görevlisi bulundurulması, güvenlik kameralarının yerleştirilmesi, kartlı sistemlerle giriş-çıkışların kontrol altında tutulması, mekânsal düzenlemelerle bireylerin çevrelerinde neler olup bittiğini görmelerini sağlayacak doğal gözetim ortamının oluşturulması gibi (Dolu, 2009, s.19).

Durumsal suç önleme, özellikli suç kategorileri için gerekli fırsatları, bu fırsatlara eşlik eden riskleri ve zorlukları artırarak ve ulaşılacak ödülleri sınırlayarak suçları azaltmayı hedeflemektedir. Yöntem, üç unsurdan oluşmaktadır:

- İyi tanımlanmış teorik altyapı,

- Belirli suç problemleri ile başa çıkmak için standart bir metodoloji,

- Çeşitli fırsat azaltıcı tekniklerden oluşmaktadır.

Teorik altyapı, suç teorileri arasında yer alan, rutin aktivite ve rasyonel seçim teorileri gibi bir grup "fırsat" teorileri ile açıklanmaktadır. Standart metodoloji, problemi analiz etme ve tanımlama, muhtemel çözümleri tespit edip ortaya koyma, sonuçları değerlendirme ve yayma amacıyla araştırmacıların uygulamacılarla birlikte çalıştığı eylem araştırması paradigmasının bir versiyonudur. Fırsat azaltıcı teknikler ise suç düşüncesine sahip potansiyel kişilerin eyleme geçmeden caydırmaya yönelik yapılan uygulamalardır (Clarke, 2014, s.1).

\subsubsection{Sosyal Çevre İçin Kampüste Peyzaj Tasarımı ile Davranışsal Önlemler Alma}

Kriminolojide mekânın özelliklerine dikkat çeken akım, "Çevresel Tasarım ile Suç Önleme" (Crime Prevention Through Environmental Design-CPTED) teorisi, ilk olarak, bir kriminolog olan C. Ray Jeffery (1971) tarafından ortaya atılmış ve Timothy D. Crowe tarafından geliştirilmiştir (Çelik, 2018, s.77). Ray Jeffery (1971) Çevresel Tasarım ile Suçun Önlenmesi 
(Crime Preventing Through Environmental Design) isimli kitabında, klasik kriminoloji okulunun temel prensibi olan suç işleme potansiyeli olan kişiyi caydırmak ilkesini koruyarak suçlunun kendisinden çok suçun işlendiği çevreye odaklanmak istemiştir. Çevresel tasarım ile suçun önlenmesi konsepti Jeffery'nin Washington'da gençlerin okuduğu bir okul çevresini kontrol etmeyi hedefleyen bir projedeki deneyimlerinden kaynaklanmıştır (Cicerali ve Cicerali, 2018, s.102). Çevresel tasarım yoluyla suç önleme yaklaşımı, fiziksel ortamı manipüle edip olumlu davranışsal etkiler yaratarak güvenlik algısını arttırmakta; suç faaliyeti ve suç korkusunu azaltmaktadır (Fernandez, 2005, s.9).

Crowe (2000), yapılandırılmış çevrenin uygun ve etkili kullanımının, suçun işlenme korkusunu ve suçun sıklığını azaltarak, yaşam kalitesinin arttırılmasına katkı sunduğunu ifade etmektedir. Tasarım ile suç önleme uygulamalarının 3 ana stratejisi vardır. Bunlar, doğal erişim kontrolü, doğal gözetim ve bölgesel uygulamadır. Bu üç strateji, insanların yaşamak, çalışmak, seyahat etmek veya ziyaret etmek için oluşturdukları ve kendilerini güvende hissettikleri bir ortam yaratmak için birlikte çalışmaktadır (Crowe, 2000, s.36).

Doğal erişim kontrolü: Bir bölgeye, amaçlanan ve istenen kullanıcıların dışındaki kullanıcıların erişimini engellemek için bitkiler (ağaçlar ve çalılar), sınır elemanları (duvar ve çitler), kapılar ve diğer fiziksel elemanlar kullanılarak sağlanır.

Doğal gözetim: Amaçlanan ve istenen kullanıcılara çevreyi görme imkânı verirken, davetsiz ve istenmeyen kişilerin de görülmesini sağlar. Çevreyi görme, yeterli aydınlatma ve engelsiz görüş sağlayan peyzaj tasarımı ile geliştirilebilir.

Bölgesel uygulama: Kamu ve özel mülkiyet ayrımının ön plana çıkarılmasını öngören bir stratejidir. Kamu ve özel alanlar arasındaki sınırların, kaldırımlar, yeşil alanlar, duvarlar gibi fiziksel unsurlarla belirlenmesidir (Crowe, 2000, s.36).

\section{MATERYAL VE YÖNTEM}

\subsection{Materyal}

Çalışma alanı, Selçuk Üniversitesi, Alaeddin Keykubad Kampüsü'dür. Kampüs, Selçuklu İlçesi sınırları içinde, Konya kent merkezinin 20 km kuzeyinde ve Afyonkarahisar karayolu üzerinde yer almaktadır. 14,5 milyon $\mathrm{m}^{2}$ alan kaplayan Alaeddin Keykubad Kampüsü'nde;

- 20 fakülte (Diş Hekimliği, Eczacılık, Edebiyat, Eğitim, Fen, Güzel Sanatlar, Hukuk, İktisadi ve İdari Bilimler, İletişim, İslami İlimler, Mimarlık, Mühendislik, Sağlık Bilimleri, Sanat ve Tasarım, Spor Bilimleri, Teknoloji, Tıp, Turizm, Veteriner ve Ziraat Fakülteleri),

- 3 yüksekokul (Beden Eğitimi ve Spor, Sivil Havacılık ve Yabancı Diller Yüksekokulları),

- 4 meslek yüksekokulu (Adalet, Sağlık Hizmetleri, Sosyal Bilimler ve Teknik Bilimler Meslek Yüksekokulları),

- 1 konservatuvar (Dilek Sabancı Devlet Konservatuarı),

- 6 enstitü (Eğitim Bilimleri Enstitüsü, Fen Bilimleri Enstitüsü, Mevlâna Araştırmaları Enstitüsü, Sağlık Bilimleri Enstitüsü, Sosyal Bilimler Enstitüsü ve Türkiyat Araştırmaları Enstitüsü),

- Rektörlüğe bağlı birimler (Atatürk İlkeleri ve İnkılap Tarihi Bölümü ve Türk Dili Bölüm Başkanlığı),

- 44 araştırma ve uygulama merkezi,

- 17 koordinatörlük,

- Teknokent,

- İdari birimler (rektörlük ve genel sekreterlik),

- Polis merkezi (URL-3, 2018).

- Otoparklar, ulaşım ağı (yaya, bisiklet ve araç yolları, tramvay hattı), yurtlar, lojmanlar, kütüphane, hastane, misafirhane, Erasmus Evi, cami, hobi bahçeleri, kapalı yüzme havuzu, kapalı spor salonu, spor tesisleri (tenis kortları ve basketbol sahası), stadyum, amfi, meydan, ısı merkezi, yeme-içme ve alış-veriş mekanları da yer almaktadır (Şekil 1) (Çelik vd. 2018, s.228). 


\subsection{Yöntem}

Araştırma Tasarımı, Veri Toplama Aracı ve Araştırmanın Örneklemi: Suç korkusu, insanların tehlike, tehdit, risk, kaygı ve endişe gibi uyarıcılar karşısında ortaya çıkan algı, his ve duygu durumlarını ifade etmektedir. İnsanların güvensiz hissettikleri ve korku duydukları mekanları, durumları, olayları ve kişileri tespit etmek için en etkili yöntem suç korkusu belirleme veya ölçme anketi uygulamaktır (Bedimo-Rung vd, 2005, s.165; Çoklar ve Solak, 2017, s.316). Bu araştırmada ise niceliksel (anket) ve niteliksel (katılımcı gözlem ve algısal değerlendirme) sorgulama yöntemine göre öğrencilerin Alaeddin Keykubad Kampüsü'nün fiziksel çevresine ilişkin suç korkusu belirlenmeye çalışılmıştır.

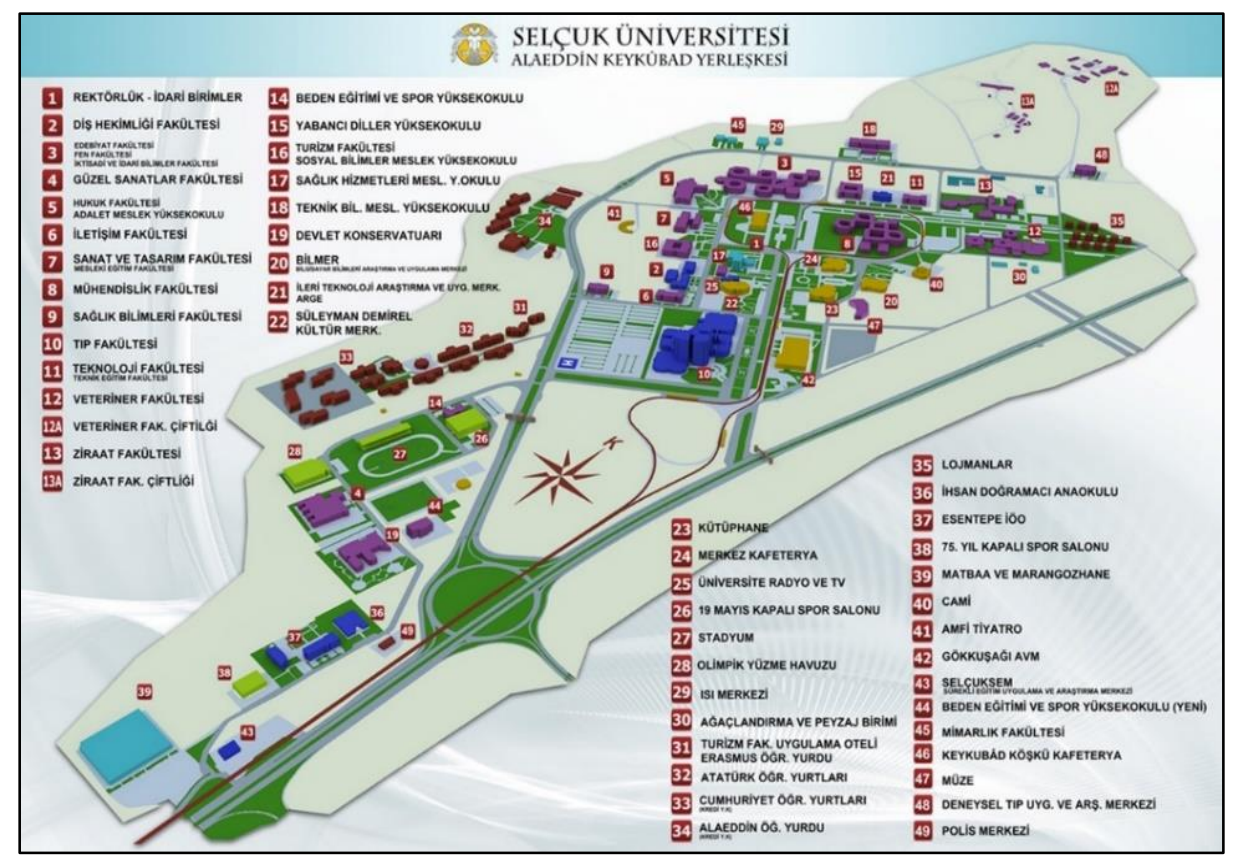

Şekil 1. Alaeddin Keykubad Kampüsü birimleri (URL-3)

Anket formu kişisel bilgiler, kampüs güvenliği ve suç korkusunu belirlemeye yönelik 3 bölümden oluşmaktadır. Ankette açık ve kapalı uçlu sorular ile ölçek yer almaktadır. Öğrencilerin kişisel bilgilerinin belirlenmesine yönelik bölümde açık ve kapalı uçlu sorulara yer verilmiş; kampüste güvenlik algısı ve suç korkusunu belirlemek için oluşturulan sorular ise $5^{\prime}$ li likert ölçeği ve sıralama (ordinal) ölçeği ( $1=$ çok güvenli; $2=$ güvenli; $3=$ ne güvenli/ne güvensiz; 4 =güvensiz; 5 =çok güvensiz), ( 1 =asla; 2 =nadiren; 3 =bazen; 4 =genellikle; 5 =her zaman) ile derecelendirilmiştir.

Sorular hazırlanırken "Kampüs Güvenliği ve Güvenlik Raporlaması El Kitabı" (The Handbook for Campus Safety and Security Reporting) (URL-4, 2016), "Uluslararası Suç Mağduriyeti Anketi" (International Crime Victimization Survey-ICVS) (Van Dijk et al., 1990) ve "Suç Korkusu Mağduriyet Riskini Yorumlama" (The Fear of Crime Interpreting Victimization Risk) (Ferraro, 1995, s.35-38) isimli çalışmalarda yer alan suç korkusu ölçeğinden yararlanılmıştır. Ayrıca kampüste yapılan katııımcı gözlem ve önceki çalışmaların incelenmesi sonucunda elde edilen veriler de kullanılmıştır. Hazırlanan anketin yeterli ve anlaşıır olduğunu belirlemek için pilot uygulama yapılmış; katılımcılardan sorular hakkında yorum yapmaları istenmiş ve geri bildirimler doğrultusunda ankette değişiklikler yapılmıştır.

Araştırmanın evrenini, Selçuk Üniversitesi, Alaeddin Keykubad Kampüsü'nde öğrenim gören toplam 77.783 ön lisans, lisans ve lisansüstü öğrencileri oluşturmaktadır (URL-5, 2018). Evrenin tamamına ulaşmak mümkün olmadığı için zaman sınırlandırıcı faktör olarak kabul edilmiş; anketler 1-30 Haziran 2018 tarihleri arasında uygulanmış ve 225 öğrenciden (araştırmanın örneklemi) gelen geri bildirimler doğrultusunda değerlendirme yapılmıştır. Anketler, öğrencilere elektronik ortamda, e-posta ve sosyal medya aracılığıyla uygulanmıştır. Zamanın 30 günle sınırlı olmasına rağmen öğrencilerin gönüllü olarak ankete katılmaları ve 
anketin elektronik ortamda uygulanması ile oldukça geniş bir katılım sağlanmışır. Bu durum çalışmanın güvenilirliği, geçerliliği ve evreni yansıtma oranını arttırmaktadır.

Değerlendirme: Anketlerin değerlendirmesi için SPSS 21.00 istatistik paket programı kullanılmıştır. Güven aralığı \%95 ve anlamlılık düzeyi $p<0,05$ olarak alınmıştır. Güvenlik algısı, suç korkusu ve endişe duyma ile ilgili tanımlayıcı istatistikler (frekans ve yüzde değerleri, aritmetik ortalama, standart sapma, standart hata) yapılmıştır. İki yönlü analizlerle hem bağımlı (yaş, cinsiyet) ve bağımsız değişkenler (güvenlik algısı, suç korkusu, endişe duyma) arasındaki hem de bağımsız değişkenlerin kendi aralarındaki ilişkiler incelenmiştir.

Katılımcı Gözlem: Araştırılan objenin ya da topluluğun günlük yaşamına katılma yoluyla yapılacak gözlemde, araştırmacının, araştırdığı grupla birlikte bir süre yaşaması, onların yaşamlarında yer alması gereklidir. Böylece araştırmacı, araştırdığı grubun davranış biçimlerini, değer sistemini, birbirleriyle olan ilişkilerini, toplumsal, ekonomik ve kültürel özlü olaylar, törenler çerçevesindeki kümelenişlerini, rollerini, tutum ve tavır alışlarını yakından gözleme olanağı bulur (Balcı, 2015).

Kampüste farklı zamanlarda (sabah-öğle-akşam-gece, hafta içi-hafta sonu) yapılan katılımcı gözlem ile öğrencilerin kampüsteki günlük yaşamına katılarak kampüste suç korkusu oluşturabilecek mekanlar ve faktörler belirlenmiştir.

Sonuç: Katılımc gözlem ve anket sonucu elde edilen niteliksel ve niceliksel veriler kullanılarak öğrencilerin algıları doğrultusunda yapılan değerlendirme ile Alaeddin Keykubad Kampüsü'nde mekândan kaynaklanan suç korkusu belirlenmiştir.

\section{BULGULAR}

\subsection{Araştırmanın Sınırlılıkları}

Selçuk Üniversitesi, Koruma ve Güvenlik Müdürlüğü'nden Alaeddin Keykubad Kampüsü'nde suç türleri ve istatistikleri konusunda veri temin edilememiştir. Ayrıca kampüs sınırları içerisinde Polis Merkezi bulunmasına rağmen kampüsteki suç olayları hakkında bilgi alınamamıştır. Bu nedenle anket soruları, suç korkusu ile ilgili daha önce yapılan çalışmalar temel alınarak hazırlanmıştır.

Suç korkusu, bazı olayların dayandığı neden veya bu nedenlerin yol açtığı algıya dayalı sonuç olduğu için belirlenmesi, ölçülmesi ve analiz edilmesi oldukça güçtür. Ferraro (1995) suç korkusu araştırılırken, duyguların gizlenmek istenmesi nedeniyle, duygusal durum yerine fiziksel çevreye yönelik yargıların belirlenmesi ve ölçülmesi gerektiğini ifade etmiştir. Bu bağlamda anket soruları hazırlanırken, öğrencilerin kampüsün fiziksel çevresine ilişkin suç kokusunu ifade eden yargıları seçmelerini sağlayacak şekilde hazırlanmış ve her sorunun cevaplanması zorunlu tutulmuştur.

Suç korkusu ve suça maruz kalma, insanların kolaylıkla ifade edebilecekleri bir durum değildir. $\mathrm{Bu}$ nedenle bazı sorulara gerçek cevabın verilmeme olasıı̆ı bulunmaktadır. Özellikle cinsel taciz veya cinsel saldırıya uğramak gizli tutulabilir. Ayrıca erkeklerin de korkularını gizleme eğilimi vardır. Bu durumların gizli tutulmak istenmesi, gerçeğin açı̆̆a çıkarılması ve yorumlanmasında sınırlıı̆a neden olabileceği göz önünde bulundurulmuştur.

\subsection{Alaeddin Keykubad Kampüsü'nde Suça Potansiyel Olabilecek Alanlar}

Kampüste sabah-öğle-akşam-gece ve hafta içi-hafta sonu olmak üzere farklı zamanlarda katıımcı gözlem yapılmıştır. Öğrencilerin kampüsteki günlük yaşamına katılarak kampüste suç korkusu oluşturabilecek mekanlar ve faktörler belirlenmiştir:

- Kampüsün 4 ana giriş-çıkış noktası bulunmakta ancak bu noktalarda yaya ve araç kontrolü yapılmamaktadır.

- Kampüs içinden geçerek ulaşım sağlanan Ardıçlı ve Yükselen Mahalleleri'ne giden yollar da kontrolsüz olduğu için güvensiz ve suç korkusuna neden olabilecek niteliktedir.

- Kampüste bakımsız ve köhne yerlerin olması, suç oluşumu ve suçlular için fırsat sunmaktadır (Şekil 2). 
- Kampüste devam eden inşaatlar da bakımsız ve köhne yerlerde olduğu gibi suç oluşumu ve suçlular için fırsat oluşturma potansiyeline sahiptir (Şekil 2).

- Kampüsün bazı bölgelerinde aydınlatma yetersiz olup karanlık bölgeler bulunmaktadır. Karanlık bölgeler, mekânda suç oluşumu ve suç korkusu için zemin oluşturmaktadır.

- Bitki örtüsünün özellikle ağaç ve çalıların yoğun olduğu yerlerde kör noktalar oluşmaktadır. Yoğun bitki örtüsü ile birlikte yetersiz aydınlatma olan yerler, karanlık, loş ve güvensiz bölgeler oluşmaktadır (Şekil 3).

- Kampüsü çevreleyen ağaçlandırılmış alanlar, yoğun bitki örtüsü nedeniyle özellikle gece karanlık, ıssız ve ürkütücü olmaktadır. Bu alanlarda yılan, tilki, kurt gibi yaban hayvanlarına rastlamak mümkündür.

- Tramvayın kampüse giriş yaptığı ilk nokta, karmaşık ve kontrolsüz olduğu için risk oluşturmaktadır (Şekil 4).
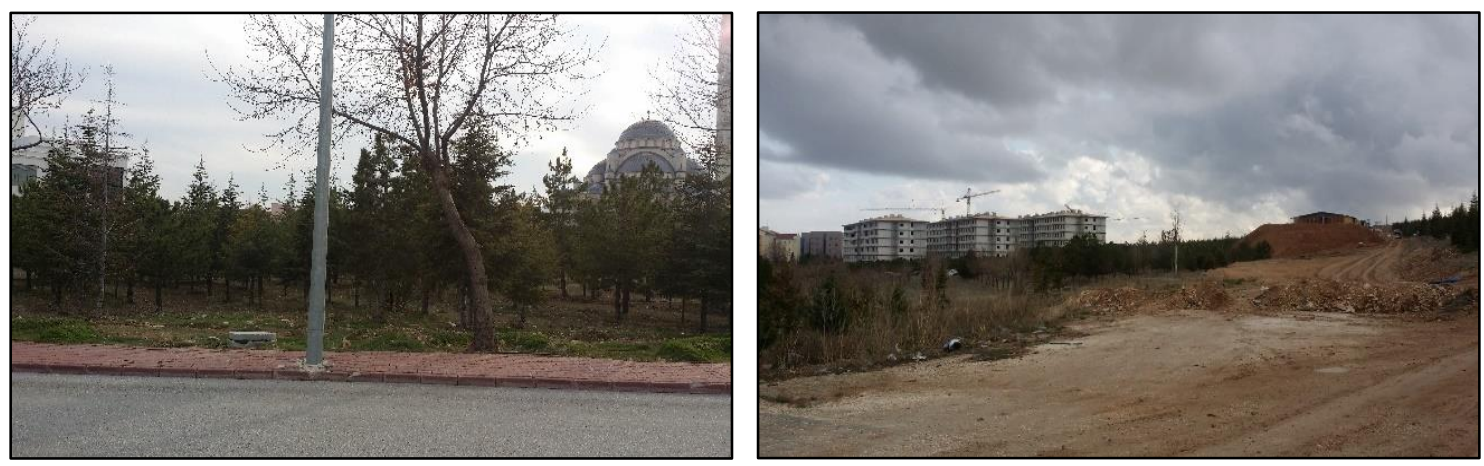

Şekil 2. Kampüste devam eden inşaatlar, bakımsız ve köhne yerler (Orijinal, 2018)
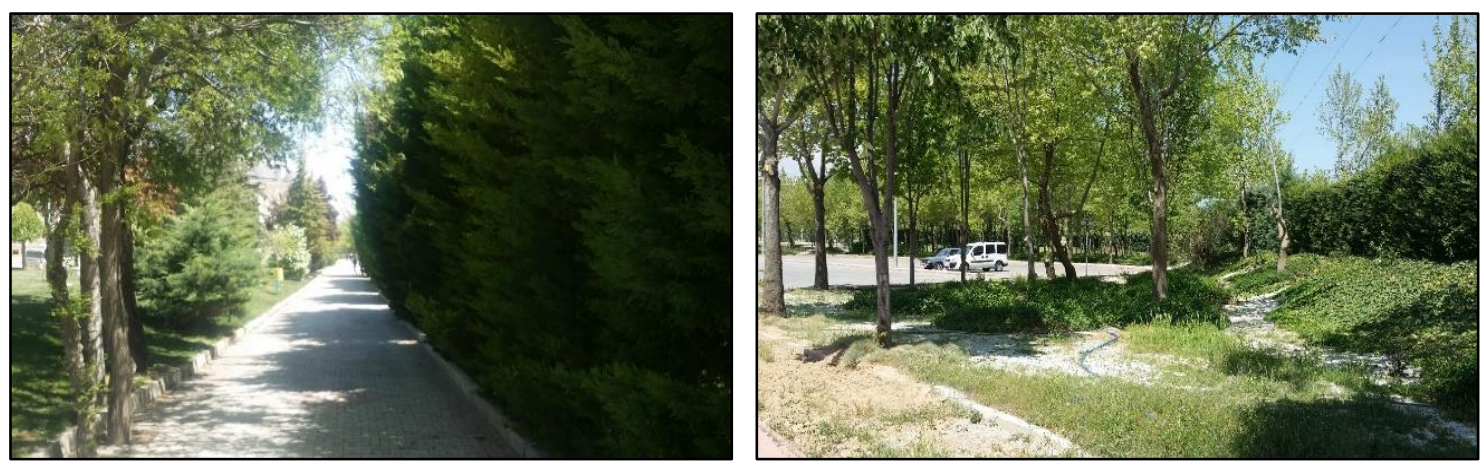

Şekil 3. Bitki örtüsünün yoğun olduğu yerler (Orijinal, 2018)
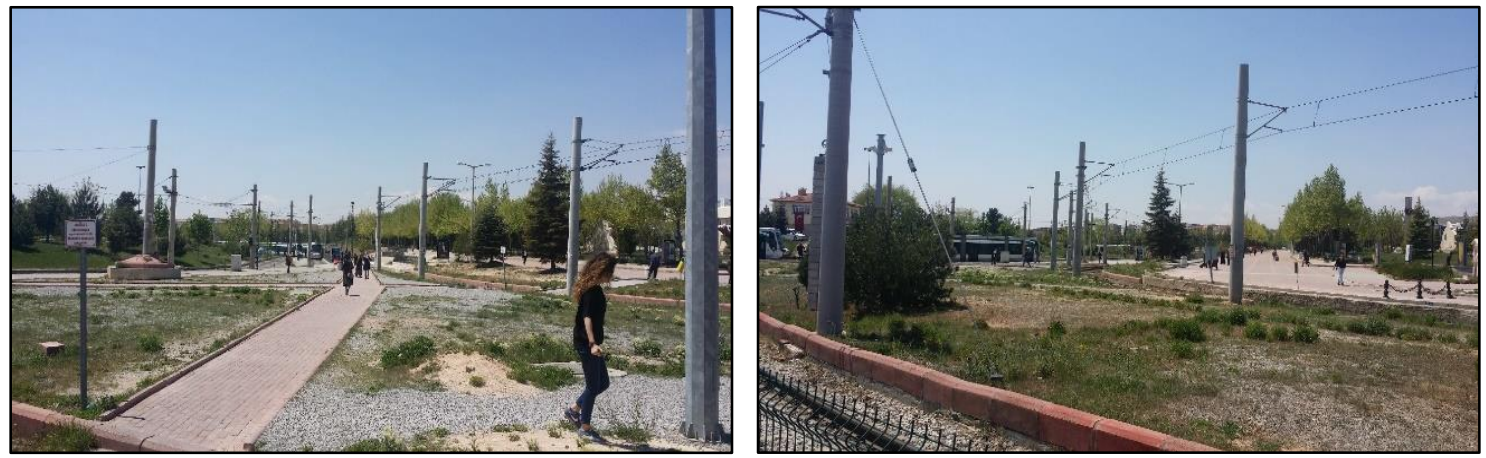

Şekil 4. Tramvayın kampüse giriş yaptığı bölge (Orijinal, 2018)

\subsection{Değerlendirme}

1-30 Haziran 2018 tarihleri arasında anketleri cevaplayan 225 öğrenciden \%64,9'u kız, \%35,1'i erkek öğrencidir. Öğrenciler anketi kendi istekleri ile cevapladığı için kız öğrencilerin erkek öğrencilere göre yüksek oranda katılımı, suç korkusu konusunda kız öğrencilerin daha hassas 
ve tedirgin olduğunu düşündürmektedir. Örneklemi oluşturan öğrencilere ilişkin yaş, öğrenim düzeyi, öğrenim aşaması ve barınmaya ait tanımlayıcı bilgiler Tablo 1'de görülmektedir.

Kampüste güvenlik algısı, gündüz ve gece farklılığına göre ele alınmıştır. Buna göre öğrencilerin $\% 44,9$ 'u kampüsü gündüz güvenli olarak algıladığını; \%34,7'si ise gece bazen güvenli, bazen güvensiz olarak algıladığını belirtmiştir (Tablo 2). Yapılan çalışmalar, çoğu mekânın gündüz güvenli algılanmasına rağmen aynı mekânda insanların gece suç korkusu yaşadığını ortaya koymaktadır.

Cinsiyet ve kampüste gündüz-gece farklılığına göre güvenlik algısına bakılacak olursa; kız öğrencilerin \%66, $9^{\prime}$ u, erkek öğrencilerin de $\% 71,2$ 'si gündüz güvenli olarak nitelendirirken; kız öğrencilerin \%46,7'si, erkek öğrencilerin ise \%59,5'i gece güvenli olarak nitelendirmiştir. Bu sonuca göre kız öğrencilerin erkek öğrencilere göre kendilerini daha az güvende hissettikleri yani bir suçun mağduru olma konusunda daha endişeli oldukları söylenebilir. Hem kız hem de erkek öğrencilerin kampüste gece güvenlik algısı gündüze göre daha düşük olup gündüz ve gece arasındaki fark oldukça dikkat çekicidir (Tablo 3).

Tablo 1. Öğrencilere ilişkin tanımlayıı bilgiler

\begin{tabular}{|c|c|c|c|}
\hline Değişkenler & Grup & Sayı (N) & Yüzde (\%) \\
\hline \multirow{2}{*}{ Cinsiyet } & $\mathrm{KIZ}$ & 146 & 64,9 \\
\hline & Erkek & 79 & 35,1 \\
\hline \multirow{9}{*}{ Yaş } & 18 & 5 & 2,2 \\
\hline & 19 & 29 & 12,9 \\
\hline & 20 & 34 & 15,1 \\
\hline & 21 & 50 & 22,2 \\
\hline & 22 & 36 & 16 \\
\hline & 23 & 23 & 10,2 \\
\hline & 24 & 6 & 2,7 \\
\hline & 25 & 8 & 3,6 \\
\hline & 26 ve üstü & 34 & 15,1 \\
\hline \multirow{3}{*}{ Öğrenim düzeyi } & Lisansüstü & 14 & 6,3 \\
\hline & Lisans & 195 & 86,6 \\
\hline & Ön lisans & 16 & 7,1 \\
\hline \multirow{7}{*}{ Öğrenim aşaması } & Hazırlık & 20 & 8.9 \\
\hline & 1. sinıf & 44 & 19.6 \\
\hline & 2. sinıf & 40 & 17.8 \\
\hline & 3. sinıf & 47 & 20.9 \\
\hline & 4. sinıf & 59 & 26.2 \\
\hline & 5. sinıf & 6 & 2.7 \\
\hline & 6. sinıf & 9 & 4 \\
\hline \multirow{3}{*}{ Barınma } & Evde & 118 & 52,4 \\
\hline & Kampüs dışındaki yurtta & 63 & 28 \\
\hline & Kampüs içindeki yurtta & 44 & 19,6 \\
\hline
\end{tabular}

Tablo 2. Kampüste gündüz ve gece güvenlik düzeyi

\begin{tabular}{|c|c|c|c|c|c|}
\hline $\begin{array}{l}\text { Kampüste } \\
\text { güvenlik düzeyi }\end{array}$ & $\begin{array}{l}\text { Çok } \\
\text { güvenli }\end{array}$ & Güvenli & $\begin{array}{l}\text { Bazen güvenli/ } \\
\text { Bazen güvensiz }\end{array}$ & Güvensiz & $\begin{array}{l}\text { Çok } \\
\text { güvensiz }\end{array}$ \\
\hline Gündüz & $\% 7,1$ & $\% 44,9$ & $\% 33,8$ & $\stackrel{\% 11,1}{\longrightarrow}$ & $\% 3,1$ \\
\hline Gece & $\% 2,2$ & $\% 17,8$ & $\% 34,7$ & $\% 24,4$ & $\stackrel{\% 20,9}{\longrightarrow}$ \\
\hline
\end{tabular}


Tablo 3. Cinsiyet ve kampüste gündüz-gece farklılı̆ına göre güvenlik algısı

\begin{tabular}{l|c|c|c|c|c|c|c}
\hline $\begin{array}{l}\text { Kampüste } \\
\text { güvenlik düzeyi }\end{array}$ & Cinsiyet & $\begin{array}{c}\text { Güvenli } \\
(\mathbf{\%})\end{array}$ & $\begin{array}{c}\text { Güvensiz } \\
(\mathbf{\%})\end{array}$ & $\mathbf{N}$ & Ort. & $\begin{array}{c}\text { Std. } \\
\text { Sapma }\end{array}$ & $\begin{array}{c}\text { Std. } \\
\text { Hata ort. }\end{array}$ \\
\hline \multirow{2}{*}{ Gündüz } & Kadın & $\% 66,9$ & $\% 33,1$ & 146 & 3,34 & 0,792 & 0,66 \\
\cline { 2 - 8 } & Erkek & $\% 71,1$ & $\% 22,9$ & 79 & 3,56 & 1,047 & 1,118 \\
\hline \multirow{2}{*}{ Gece } & Kadın & $\% 46,7$ & $\% 53,3$ & 146 & 2,34 & 0,978 & 0,081 \\
\cline { 2 - 8 } & Erkek & $\% 59,5$ & $\$ 40,5$ & 79 & 2,97 & 1,132 & 0,127 \\
\hline
\end{tabular}

Kampüste güvensiz hissettiren yerler arasında ilk 3 sırada kalabalık yerler, bakımsız ve köhne yerler ile giriş-çıkış noktaları yer almaktadır (Tablo 4). Kalabalık yerler, tanınmayan ve kampüse dışarıdan gelen insanların bulunması; bakımsız ve köhne yerler, mekânsal düzensizlik nedeniyle endişenin ve tedirginlik yaratması; giriş-çıkış noktaları ise kontrol olmaması nedeniyle güvensiz algılanmaktadır. Tablo 4 'te güvensiz hissedilen yerler sıralamasında en altta yer alan ortak kullanım alanları, tramvay durakları ve eğitim binalarının yakın çevresi yardıma erişim fırsatı sunduğu için daha güvenli olarak nitelendirilebilir.

Tablo 4. Kampüste güvensiz hissettiren yerler

\begin{tabular}{l|r|r}
\hline Kampüste güvensiz hissettiren yerler & Sayı (N) & Yüzde (\%) \\
\hline Kalabalık yerler & 118 & 19,4 \\
\hline Bakımsız ve köhne yerler & 104 & 17,1 \\
\hline Giriş-çıkış noktaları & 98 & 16,1 \\
\hline Net görülmeyen yerler & 78 & 12,8 \\
\hline Sakin yerler & 58 & 9,5 \\
\hline Karanlık yerler & 52 & 8,6 \\
\hline Ağaç ve çalıların yoğun olduğu yerler & 51 & 8,4 \\
\hline Devam eden inşaatlar & 26 & 4,3 \\
\hline Ortak kullanım alanları & 13 & 2,1 \\
\hline Tramvay durakları & 7 & 1,2 \\
\hline Eğitim binalarının yakın çevresi & 3 & 0,5 \\
\hline Toplam & 608 & 100 \\
\hline
\end{tabular}

Suç korkusu, suçun kendisinden çok bireysel ve toplumsal bir sorun olup hızla yaygınlaşmakta ve artmaktadır. Suç korkusunun öğrenciler tarafından nasıl algılandığını tespit etmek için kampüste korkuya neden olan faktörler ve kampüsün belirli mekanlarında suça maruz kalma korkuları belirlenmeye çalışılmıştır. Çalışmaya katılan öğrencilerin $\% 57,8^{\prime} \mathrm{i}$ asla kampüste suç hakkında endişelenmediğini belirtirken, \%42,2'si nadiren endişe duyduğunu belirtmiştir. Bazen insanlar, korku ve endişelerini gizlemeye ve belli etmemeye çalışırlar. Bu nedenle bu soruya gerçek cevabın verilmeme intimali de yüksektir. Cinsiyet ve suç hakkında endişe duyma arasında istatistiki olarak anlamlı bir ilişki vardır ve ilişkinin yönü negatiftir. Kız öğrencilerin $\% 64,4$ 'ü, erkek öğrencilerin de \%45,6'sı kampüste suç hakkında endişeli olduğunu ifade etmiştir. Özellikle erkeklerin korkularını gizleme eğilimi olduğu için bu sonuç gerçeği yansıtmayabilir ve erkek öğrencilerin suç hakkında endişe duyma oranı daha fazla olabilir.

Yapılan çalışmalar, bir bölgede ikamet etme veya yaşama süresi ile suç korkusu arasında anlamlı bir ilişki olduğunu ortaya koymuştur. Yaşanılan çevreyi tanıma ve deneyimleme süresi arttıkça güvenlik algısı olumlu, suç korkusu ise daha az olmaktadır (Ferraro, 1995; Kul, 2013; Karakaya, 2015; Sipahi, 2017). Bu nedenle öğrencilerin kampüste öğrenim süresi ile suç hakkında endişelenme arasındaki incelendiğinde öğrenim süresi arttıkça suç hakkında endişelenme oranı düşmektedir ancak \%58,3 yine de çok yüksek bir orandır (Tablo 5). 
Tablo 5. Kampüste öğrenim süresi ve suç hakkında endişelenme arasındaki ilişki

\begin{tabular}{l|r|c|c}
\hline \multicolumn{2}{c|}{$\begin{array}{c}\text { Kampüste öğrenim süresi } \\
(\%)\end{array}$} & \multicolumn{2}{c}{ Suç hakkında endişeleniyorum } \\
\cline { 3 - 4 } & 11.6 & Evet (\%) & Hayır (\%) \\
\hline $\mathbf{1}$ yıldan az & 13.3 & 66,9 & 23,1 \\
\hline $\mathbf{1}$ yıl & 23.6 & 49,1 & 36,7 \\
\hline $\mathbf{2}$ yıl & 21.3 & 56,3 & 50,9 \\
\hline $\mathbf{3}$ yıl & 20.4 & 52,2 & 43,8 \\
\hline $\mathbf{4}$ yıl & 4.4 & 70 & 47,8 \\
\hline $\mathbf{5}$ yıl & 5.3 & 58,3 & 30 \\
\hline $\mathbf{6}$ yıl ve üstü & & & 41,7 \\
\hline
\end{tabular}

Öğrencilerin kendilerini güvensiz hissetmelerine neden olan suç türlerini belirlemek amacıyla suç türlerine ilişkin yargıları seçmeleri için her sorunun cevaplanması zorunlu tutulmuştur. Kampüste güvensiz hissetme nedeni olarak tehdit edilme, hırsızlık, fiziksel, sözlü ve cinsel saldırı gibi suçlardan korkmanın ne derecede etkili olduğu belirlenmeye çalışılmıştır. Öğrencilerin \%31,6'sı kampüste güvensiz hissetme nedeni olarak suç korkusunun çok etkili olduğunu, \%26,2'si etkili olduğu, \%21,3'ü bazen etkili-bazen etkisiz olduğunu, \%15,6'sı etkisiz olduğunu ve \%5,3'ü ise tamamen etkisiz olduğunu ifade etmiştir. Cinsiyet ve suç korkusu arasında istatistiki olarak anlamlı bir ilişki vardır ve ilişkinin yönü negatiftir. Kız öğrencilerin $\% 78$ 'i, erkek öğrencilerin ise \%62,5'i suç korkusu nedeniyle güvensiz hissettiğini belirtmiştir. Bu sonuçlara göre kız öğrencilerin erkek öğrencilere göre daha fazla suç korkusu yaşadıkları ortaya çıkmaktadır. Bu durum, daha önce yapılan çalışmalarda ortaya koyulan, kadınların erkeklere oranla daha fazla suç korkusu taşıdığı sonucunu desteklemektedir.

"Kampüste suça maruz kaldınız mı?" sorusuna öğrencilerin \%85,8'i hayır; \%14,2'si evet cevabını vermiştir. Kampüste suça maruz kalan 32 öğrenciden 23'ü sözlü saldırı, 3'ü fiziksel saldırı, 2'si cinsel saldırı, 2'si tehdit dilme ve 2'si de hırsızlık suçuna maruz kaldığını belirtmiştir. Bu sonuçlar gerçekleri yansıtamayabilir. Özellikle cinsel saldırı, insanların kolaylıkla ifade edebileceği bir durum olmadığı için gizli tutulabilir. Bu nedenle cinsel saldırı oranları gerçekte daha fazla olabilir.

Barınma ile kampüste suça maruz kalma arasındaki ilişkiye bakılacak olursa evde $(\% 13,6)$ ve kampüs dışındaki yurtlarda $(\% 14,3)$ barınan öğrencilerin kampüste suça maruz kalma oranı nispeten düşüktür ancak kampüs içindeki yurtlarda (\%15,9) barınan öğrencilerle arasında büyük bir fark yoktur. Barınma ile kampüste maruz kalınan suç türleri arasındaki ilişkiye de bakılacak olursa evde ve kampüs dışındaki yurtlarda barınan öğrencilerin kampüsü deneyimleme süresi daha az olduğu için maruz kalınan suç türleri kampüs içindeki yurtlarda barınan öğrencilere göre daha düşüktür (Tablo 6).

Tablo 6. Barınma ile kampüste suça maruz kalma ve suç türleri

\begin{tabular}{l|c|c|c|c|c|c|c}
\hline \multirow{2}{*}{ Barınma } & \multicolumn{6}{|c|}{$\begin{array}{l}\text { Kampüste } \\
\text { maruz kaldınız mı? }\end{array}$} & \multicolumn{5}{|c}{$\begin{array}{c}\text { Ne tür suça maruz kaldınız? } \\
\text { (\%) }\end{array}$} \\
\cline { 2 - 8 } & Evet & Hayır & $\begin{array}{l}\text { Cinsel } \\
\text { saldırı }\end{array}$ & $\begin{array}{l}\text { Fiziksel } \\
\text { saldırı }\end{array}$ & $\begin{array}{l}\text { Sözlü } \\
\text { saldırı }\end{array}$ & Hırsızlık & $\begin{array}{c}\text { Tehdit } \\
\text { edilme }\end{array}$ \\
\hline Evde & 13,6 & 86,4 & 0,8 & $X$ & 11,9 & 0,8 & $X$ \\
\hline Kampüs dışı yurtta & 14,3 & 85,7 & $X$ & 3,2 & 9,5 & $X$ & 1,6 \\
\hline Kampüs içi yurtta & 15,9 & 84,1 & 2,3 & 2,3 & 6,8 & 2,3 & 2,3 \\
\hline
\end{tabular}

Cinsiyet ile kampüste suça maruz kalma arasındaki ilişkiye göre kız öğrencilerin suça maruz kalma oranı $(\% 15,8)$ erkeklere $(\% 11,4)$ göre daha yüksektir (Tablo 7$)$. Kız öğrenciler cinsel saldırı, fiziksel saldırı, sözlü saldırı, hırsızlık ve tehdit edilmeye maruz kaldığını belirtirken erkek öğrenciler hırsızlık, fiziksel saldırı ve sözlü saldırıya maruz kaldığını belirtmiştir. 
Tablo 7. Cinsiyet ile kampüste suça maruz kalma ve suç türleri

\begin{tabular}{l|c|c|c|c|c|c|c}
\hline \multirow{2}{*}{ Cinsiyet } & \multicolumn{2}{|c|}{$\begin{array}{l}\text { Kampüste } \\
\text { maruz kaldınız mı? }\end{array}$} & \multicolumn{5}{|c}{ suçär suça maruz kaldınız? } \\
\cline { 2 - 8 } & Evet & Hayır & $\begin{array}{c}\text { Cinsel } \\
\text { saldırı }\end{array}$ & $\begin{array}{c}\text { Fiziksel } \\
\text { saldırı }\end{array}$ & $\begin{array}{c}\text { Sözlü } \\
\text { saldırı }\end{array}$ & Hırsızlık & $\begin{array}{c}\text { Tehdit } \\
\text { edilme }\end{array}$ \\
\cline { 2 - 8 } Kadın & 15,8 & 84,2 & 1,4 & 1,4 & 11 & 0,7 & 1,4 \\
\hline Erkek & 11,4 & 88,6 & $X$ & 1,3 & 8,9 & 1,3 & $X$ \\
\hline
\end{tabular}

Kampüste öğrencilerde korku uyandıran nedenleri belirlemek için duygusal durum yerine fiziksel çevrenin öğrencilerde oluşturduğu yargıların belirlenmesi ve etkisinin ölçülmesi hedeflenmiştir. Kampüste öğrencilerde korku uyandıran nedenlere bakılırsa "kampüse kontrolsüz giriş yapılması" \%38,2 her zaman korku uyandıırken "daha önce suça maruz kalma" $(\% 63,1)$ ve "arkadaşlarından birinin suça maruz kalması" $(\% 46,2)$ asla etkili olmadığı yönünde belirtilmiştir. "Kampüste suçla ilgili duyulan rivayetler" bazen $(\% 28,4)$, "şüpheli kişiler" ise genellikle $(\% 27,6)$ korkuya neden olmaktadır. Fiziksel saldırı $(\% 33,3)$, sözlü saldırı $(\% 26,2)$, cinsel saldırı $(\% 44,9)$, tehdit edilme $(\% 39,1)$ ve hırsızlık $(\% 33,3)$ kampüste korku uyandıran nedenler arasında yer almamaktadır (Tablo 8).

Suç korkusu ve suça maruz kalma korkusu, insanların içinde bulunduğu mekanla doğrudan ilişkili olup insanların içinde bulunduğu çevreyi nasıl algıladığı ve değerlendirdiğiyle ilgili sonuçları ortaya çıkarmaktadır. Bu nedenle öğrencilerden kampüsün belirli mekanlarında suça maruz kalma korkularını derecelendirmeleri istenmiştir. Katılımcı gözlem tekniği ile kampüste öğrencilerin suç korkusu hissedebilecekleri 15 mekân belirlenmiş ve bu mekanlara ilişkin suç korkusu seviyeleri Tablo 9'da verilmiştir. Elde edilen sonuçlara göre;

- Yoğun kullanılan mekanların (kütüphane, yemekhane, Gökkuşağı, Süleyman Demirel Kültür Merkezi ve eğitim binalarının yakın çevresi ile tramvay durakları) öğrencilerin suç korkusunu olumsuz etkilemediği saptanmıştır.

- Kampüse kontrolsüz giriş yapılması, her zaman $(\% 38,2)$ korkuya neden olurken giriş-çıkış noktalarında suça maruz kalma korkusunun nadir (\%28) olduğu belirtilmiştir.

- Öğrencilerin \%35,1'i tramvay duraklarında asla suça maruz kalma korkusu taşımadığını belirtirken azalan oranda \%32'si nadiren, \%23,6'sı bazen suça maruz kalma korkusu yaşadığını ifade etmiştir.

- Yurtlara giden yol ve yurtların yakın çevresi nadir $(\% 28,4)$ olarak suça maruz kalma korkusu ile ilişkilendirilmiştir.

- Spor sahaları ve yüzme havuzu kampüsün güneybatı çeperinde ve diğer mekanlara göre daha sakin bir bölgede yer almaktadır. Bu nedenle öğrencilerin \%29,3'ü spor sahalarının yakın çevresini bazen; \%29,3'ü ise yüzme havuzunun yakın çevresini nadir olarak suça maruz kalma korkusu ile ilişkilendirmiştir.

- Bilgisayar Merkezinin yakın çevresinde öğrencilerin \%29,8'i ve caminin yakın çevresinde ise \%32,9'u suça maruz kalma korkusunun nadir olduğunu belirtmiştir. Bilgisayar merkezi ve cami yan yana olup her ikisinin yakın çevresi yoğun bitki örtüsü ile kaplıdır. Bitkilerin yoğun olması ve görüntüyü kapatması suça maruz kalma korkusuna neden olmaktadır.

- Konservatuar, enstitüler, meslek yüksek okulları, yüksek okullar ve fakültelerin yakın çevresi öğrencilerin kullanım yoğunluğuna paralel olarak suça maruz kalma korkusundan uzak bölgeler arasındadır. 
Tablo 8. Kampüste korkuya neden olan faktörlerin derecelendirilmesi

\begin{tabular}{l|c|c|c|c|c}
\hline $\begin{array}{l}\text { Kampüste sizde korku } \\
\text { uyandıran nedenleri } \\
\text { derecelendiriniz. }\end{array}$ & Asla & Nadiren & Bazen & Genellikle & $\begin{array}{l}\text { Her } \\
\text { zaman }\end{array}$ \\
\hline Kampüse kontrolsüz giriş yapııması & $\% 4,9$ & $\% 10,2$ & $\% 20,4$ & $\% 26,2$ & $\mathbf{\% 3 8 , 2}$ \\
\hline Daha önce suça maruz kalma & $\mathbf{\% 6 3 , 1}$ & $\% 16,9$ & $\% 9,3$ & $\% 7,1$ & $\% 3,6$ \\
\hline $\begin{array}{l}\text { Arkadaşlarımdan birinin suça maruz } \\
\text { kalması }\end{array}$ & $\mathbf{\% 4 6 , 2}$ & $\% 17,3$ & $\% 17,8$ & $\% 15,1$ & $\% 3,6$ \\
\hline $\begin{array}{l}\text { Kampüste suçla ilgili duyulan } \\
\text { rivayetler }\end{array}$ & $\% 23,6$ & $\% 22,2$ & $\mathbf{\% 2 8 , 4}$ & $\% 18,7$ & $\% 7,1$ \\
\hline Šüpheli kişiler & $\% 8,4$ & $\% 19,1$ & $\% 24$ & $\mathbf{\% 2 7 , 6}$ & $\% 20,9$ \\
\hline Fiziksel saldırı & $\mathbf{\% 3 3 , 3}$ & $\% 25,3$ & $\% 17,3$ & $\% 15,6$ & $\% 8,4$ \\
\hline Sözlü saldırı & $\mathbf{\% 2 6 , 2}$ & $\% 20$ & $\% 20,4$ & $\% 20$ & $\% 13,3$ \\
\hline Cinsel saldırı & $\mathbf{\% 4 4 , 9}$ & $\% 20,4$ & $\% 13,3$ & $\% 11,1$ & $\% 10,2$ \\
\hline Tehdit edilme & $\mathbf{\% 3 9 , 1}$ & $\% 20,9$ & $\% 15,6$ & $\% 14,2$ & $\% 10,2$ \\
\hline Hırsızlık & $\mathbf{\% 3 3 , 3}$ & $\% 20$ & $\% 20,9$ & $\% 13,8$ & $\% 12$ \\
\hline
\end{tabular}

Tablo 9. Kampüste belirli bölgelerde suça maruz kalma korkusu

\begin{tabular}{l|l|l|l|l|l}
\hline $\begin{array}{l}\text { Kampüste aşağıdaki bölgelerde } \\
\text { suça maruz kalma korkunuzu } \\
\text { derecelendiriniz. }\end{array}$ & Asla & Nadiren & Bazen & Genellikle & $\begin{array}{l}\text { Her } \\
\text { zaman }\end{array}$ \\
\hline Giriş-çıkış noktaları & $\% 27,1$ & $\mathbf{\% 2 8}$ & $\% 18,2$ & $\% 13,8$ & $\% 12,9$ \\
\hline Tramvay durakları & $\mathbf{\% 3 5 , 1}$ & $\% 32$ & $\% 23,6$ & $\% 5,3$ & $\% 4$ \\
\hline Yurtlara giden yol & $\% 17,3$ & $\mathbf{\% 2 8 , 4}$ & $\% 22,7$ & $\% 22,2$ & $\% 9,3$ \\
\hline Yurtların yakın çevresi & $\% 21,8$ & $\mathbf{\% 2 8 , 4}$ & $\% 20,4$ & $\% 21,3$ & $\% 8$ \\
\hline Spor sahalarının yakın çevresi & $\% 21,8$ & $\% 28,9$ & $\mathbf{\% 2 9 , 3}$ & $\% 14,2$ & $\% 5,8$ \\
\hline Yüzme havuzunun yakın çevresi & $\% 23,1$ & $\mathbf{\% 2 9 , 3}$ & $\% 28$ & $\% 12,9$ & $\% 6,7$ \\
\hline Gökkuşağının yakın çevresi & $\mathbf{\% 3 8 , 2}$ & $\% 28$ & $\% 20,4$ & $\% 8,9$ & $\% 4,4$ \\
\hline Meydan & $\mathbf{\% 3 4 , 7}$ & $\% 30,7$ & $\% 23,1$ & $\% 7,6$ & $\% 4$ \\
\hline Kütüphanenin yakın çevresi & $\mathbf{\% 4 3 , 1}$ & $\% 25,8$ & $\% 17,8$ & $\% 9,8$ & $\% 3,6$ \\
\hline Yemekhanenin yakın çevresi & $\mathbf{\% 4 1 , 3}$ & $\% 27,6$ & $\% 18,7$ & $\% 6,7$ & $\% 5,8$ \\
\hline $\begin{array}{l}\text { Tıp Fakültesi Hastanesinin yakın } \\
\text { çevresi }\end{array}$ & $\mathbf{\% 3 0 , 7}$ & $\% 26,2$ & $\% 21,3$ & $\% 11,6$ & $\% 10,2$ \\
\hline Bilgisayar Merkezinin yakın çevresi & $\% 29,3$ & $\mathbf{\% 2 9 , 8}$ & $\% 26,7$ & $\% 9,3$ & $\% 4,9$ \\
\hline Cami yakın çevresi & $\mathbf{\% 3 1 , 1}$ & $\mathbf{\% 3 2 , 9}$ & $\% 21,8$ & $\% 7,6$ & $\% 6,7$ \\
\hline $\begin{array}{l}\text { Süleyman Demirel } \\
\text { Merkezi'nin yakın çevresi }\end{array}$ & $\mathbf{\% 3 6 , 4}$ & $\% 31,1$ & $\% 20,9$ & $\% 7,1$ & $\% 4,4$ \\
\hline Eğitim binalarının yakın çevresi & $\mathbf{\% 3 5 , 1}$ & $\% 28,9$ & $\% 22,2$ & $\% 8,4$ & $\% 5,3$ \\
\hline
\end{tabular}

\section{SONUÇ VE ÖNERÍLER}

Mekânın fiziksel ve sosyal yapısına bağlı olarak gelişen suç ve kullanıcı üzerinde neden olduğu suç korkusunun azaltılmasında güvenli mekânlar tasarlamak tüm Dünya'da gittikçe önem kazanmaktadır. Bunun gerçekleştirilmesi için yapılacak ilk aşama, güvenli kent yaklaşımları ve tasarımına temel oluşturan yöntemlerden biri olan mekândaki suç korkusunun (güvensizlik algısının) ölçümü ve ölçüm sonucunda suçun gelişimine neden olan mekânsal özelliklerin tespitidir. Bu araştırmada; öğrencilerin kampüsteki mekânsal koşulları kendi bakış açılarından yorumlayarak algıya dayalı bir risk değerlendirmesi yapmaları istenmiştir. Elde edilen sonuçlar, güvenlik ve suç korkusuyla ilgili teorilerle ve ulusal-uluslararası çalışmalarda ortaya koyulan sonuçlarla örtüşmektedir. Bu araştırmanın sonuçları, kampüste kontrolsüz giriş, gecenin karanlık etkisi, suçla ilgili duyulan rivayetler ve şüpheli kişilerin suç korkusunu arttırdığını ortaya koymaktadır. Ayrıca suça maruz kalma korkusu ve suç hakkında endişe duymanın kız öğrenciler tarafından daha çok hissedildiği doğrulanırken, öğrenciler tarafından yoğun kullanılan tramvay durakları, Gökkuşağı, meydan, kütüphane, yemekhane, Tıp Fakültesi, 
Süleyman Demirel Kültür Merkezi ve eğitim binalarının yakın çevresi gibi mekanların suç korkusunu çok fazla etkilemediği saptanmıştır.

Zamanla değişen ve dönüşen Alaeddin Keykubad Kampüsü'nün peyzajı, öğrenciler, akademik ve idari personelin suç korkusu ve güvenlik konusundaki kaygılarını giderecek şekilde ele alınmalıdır. Aynı çalışma akademik ve idari personel için de uygulanabilir. Böylece kampüste tüm kullanıcıların güvenlik algılarını ve suç korkusunu anlayarak çözümler üretmek daha etkili olacaktır.

Kampüs güvenlik rehberi oluşturularak öğrenciler, akademik ve idari personel bilgilendirilmelidir. Bu rehber, özellikle Alaeddin Keykubad Kampüsü'nde yaşamı ilk defa deneyimleyecek olan yeni öğrenciler ve göreve yeni başlayan akademik ve idari personel için çok etkili olacaktır. Selçuk Üniversitesi, "Alaeddin Keykubat Kampüsü Güvenlik Rehberi'nde

- Kampüsün sınırları, fiziksel çevresi ve ulaşım alternatifleri hakkında bilgilendirme,

- Akademik ve idari birimler ile bunların kampüsteki konumları hakkında bilgilendirme,

- Kampüste uyulması gereken kuralların (trafik kuralları, açık ve kapalı mekân kullanım kuralları gibi) açıklanması,

- Kampüste dikkat edilmesi gereken özel durumların (sis, yaban hayvanları, başı boş köpekler, yabancı kişiler) açıklanması,

- Kampüste güvenli olmayan bölgeler (kampüsü çevreleyen ağaçlık alanlar, karanlık ve loş yerlerde daha dikkatli olunması gibi) hakkında bilgilendirme,

- Kampüsteki tehdit, riskler ile suç türleri ve istatistikleri hakkında bilgilendirme,

- Öğrenciler ile akademik ve idari personelin bireysel güvenliklerini sağlamaları için kural ve uyarılara uymaları gerektiği açıklanmalı,

- Acil durumda aranacak veya ulaşılacak kişi ve numaraları içeren bir bilgilendirme olmalıdır.

Kampüste peyzaj tasarımı, uygulama ve bakım çalışmalarıyla suç önleme ve suç korkusunu azaltmaya yönelik tedbirler alınabilir. Öncelikle tüm kampüste dış mekanlarda inceleme yapılarak güvenlik açısından risk ve tehdit oluşturan bölgeler daha detaylı olarak tespit edilmelidir. Bu çalışmada kampüste suç oluşumunu kolaylaştıran ve suç korkusu yaratan yerler tespit edilmiştir. Bunun yanı sıra trafik, başı boş köpekler, şüpheli kişiler ve kampüse gelen yabancılar da güvensizlik algısı yaratmaktadır (Çelik vd., 2018, s.239). Risk ve tehdit içeren bölgelerde yeterli aydınlatma ve bitkisel tasarımla suç oluşumu önlenebilir ve böylece daha güvenli bir mekân oluşturulabilir. Karanlık ve loş yerlerde yapılacak aydınlatma ile suça işlemeye karşı psikolojik bir caydırıcılık oluşturulabilir ve öğrencilerin çevreyi daha iyi algılaması sağlanabilir. Özellikle küçük alanlarda bitkilerin görüşü engellememesi için mevcut ağaç ve çalıların formu dikkate alınarak budanması ile çevrenin görülmesi sağlanabilir. Yoğun bitki örtüsünün olduğu yerlerde aydınlatma ile korku ve tedirginlik uyandıran karanlık ve loş mekanların oluşumu önlenebilir.

Fiziksel çevrenin niteliği bireylerin güvenlik ve suç korkusu algısını belirlemektedir. Kampüste bakımsız ve köhne yerler, suç oluşumu ve suçlular için fırsat oluşturmakta; güvensizlik algısı ve suç korkusuna neden olmaktadır. Bakımsız ve köhne yerlerin periyodik bakımları yapılarak mekânsal düzensizlik giderilmelidir. Böylece kampüsün yeşil alanlarında suça yönelik izlemeleri kolaylaştırmak ve mekânın doğal yollarla kendini suça karşı koruyabilmesini sağlamak mümkündür.

Kampüste doğal gözetimle yeşil alanlarda ve bina yakın çevrelerinde, alanın içinden çevrenin ve çevreden alanın içinin rahatılıkla görülebilmesi sağlanmalıdır. Öğrencilerin çevrelerinde neler olup bittiğini görmelerini sağlayacak doğal gözetim ortamının oluşturulması, suça fırsat oluşumunu ve suçluların kolaylıkla fark edilmesini sağlayacaktır. Böylece öğrencilerin kendilerini savunma ve bireysel güvenliklerini sağlamaları daha kolay olacaktır.

Öğrenci, akademik ve idari personel için ortak mekân özelliği taşıyan Gökkuşağı ve Köşk alışveriş merkezi, yeme-içme mekanları ve sosyal tesisler yardıma erişim noktaları olarak değerlendirilebilir. Korku uyandıran, tehdit ve risk içeren acil durumlarda, öğrencilerin yardıma ulaşmaları için acil durum noktaları belirlenmelidir.

Güvenli ve suç korkusunun olmadığı bir kampüs oluşturmak, öğrenciler, akademik ve idari personelin katılımı ve sorumluluk almaları ile sağlanabilir. Öğrenciler, öncelikle kendi bireysel güvenliklerini sağlamak için bireysel tedbirleri almalıdır. Alaeddin Keykubad Kampüsü'nün suç 
korkusu olmadan güvenli algılanması, öğrencilerin kampüs yaşam kalitesini, eğitim kalitesini ve akademik başarısını arttıracaktır.

\section{KAYNAKLAR}

Anonim, 2012. Dünya Ticaret ve Finans Merkezine Doğru İstanbul Kent Güvenliği. Uluslararası Sivil Toplumu Destekleme ve Geliştirme Derneği. Ankara: Usak\&STD.

Archer, R. 2014. Examining the Relationship Between Fear of Crime, Self-Protective Behavior, and Situational Crime Prevention Among College Students, A Thesis Submitted to the Faculty of The College for Design and Social Inquiry in Partial Fulfillment of the Requirements for the Degree of Master of Science, Florida Atlantic University, Florida.

Ataç, E. (2007). Suçun Kentsel Mekandaki Algısı; Güvensizlik Hissi. Dosya 06, 55, 16-23.

Ataç, E. ve Gürbüz, D. (2009). Kentsel Mekânda Gelişen Suça Müdahale Etmede Disiplinler Arası Güvenlik Politikaları (Interdisciplinary Security Policies to Respond Crime in Urban Areas). Polis Bilimleri Dergisi, 11(1), 25-46.

Aytaç, S., Cengiz, R.C., Baştürk, Ş. ve Öngen, B. (2015). Kent Güvenliği Olarak Suç Korkusu: Bursa Örneği. (Fear of Crime as an Urban Safety: Bursa Sample) Süleyman Demirel Üniversitesi Mühendislik Bilimleri ve Tasarım Dergisi, 3(3), 259-267.

Balcl, A. 2015. Sosyal Bilimlerde Araştırma: Yöntem, Teknik ve İlkeler. Ankara: Pegem Akademi Yayıncilık.

Bedenbaugh, C. P. (2003). Measuring Fear of Crime on Campus: A Study of An Urban University. Louisiana State University and Agricultural and Mechanical College The Department of Sociology. Masters Theses, University of Louisiana at Lafayette.

Bedimo-Rung, A. L., Moven, A. J. and Cohen, D. A. (2005). The Significance of Parks to Physical Activity and Public Health a Conceptual Model, American Journal of Preventive Medicine, 28 (252), 159-168.

Brantingham, P. J., \& Brantingham, P. L. (1994). Surveying Campus Crime: What Can Be Done to Reduce Crime and Fear?, Security Journal, 5, 160-171.

Cicerali, L. K. ve Cicerali, E. E. (2018). Şehir ve Güvenlik Yaklaşımlarında Çevresel Kriminolojiye Tarihsel Bir Bakış (A Historical Developmental Look at City and Security Perspectives). İdealkent, 23 (9), 95-112.

Clarke, R. V., (1995). Situational Crime Prevention, Crime and Justice, Building a Safer Society: Strategic Approaches to Crime Prevention, 19, 91-150.

Clarke, R. V., (1997). Situational Crime Prevention: Successful Case Studies, $2^{\text {nd }}$ Edition. Monsey, New York: Criminal Justice Press.

Clarke, R. V., (2014). Durumsal (Fiziki Tedbirlerle) Suç Önleme, Suçla Mücadele ve Güvenlik (Ed.-Çev. Serkan Altuntop), Siyasal Kitabevi, Ankara.

Crowe, T. D. (2000). Crime Prevention through Environmental Design: Applicants of Architectural Design and Space Management Concepts. Boston: National Crime Prevention Institute.

Çelik, F. (2018). Kentsel Açık-Yeşil Alanlarda Güvenlik (Security in the Urban Open-Green Areas). İdealkent, 23 (9), 58-94.

Çelik, F., Gemici, R. Ö. ve Mirza, E. (2018). Öğrencilerin Alaeddin Keykubad Kampüsü Fiziksel Çevresine İlişkin Güvenlik Algıları (Students' Perceptions of Security Related to Alaeddin Keykubad Campus' Physical Environment). OPUS Uluslararası Toplum Araştırmaları Dergisi, 9(16), 216-247.

Çoklar, I. ve Solak, N. (2017). Suç Korkusu: Tanım, Ölçüm ve Belirleyiciler (Fear of Crime: Definition, Measurement, and Predictors). Nesne Psikoloji Dergisi (NPD), 2017, Cilt 5, Sayı 10, 311-328.

Del Carmen, A., Polk, O. E., Segal, C., \& Bing, R. L., (2000). Fear of Crime on Campus: Examining Fear Variables of CRCJ Majors and Nonmajors in Pre- and Post-Serious Crime Environments. Journal of Security Administration, 23, 21-36. 
Dolu, O., (2009). Bir Fırsat Olarak Suç: Suçun Durumsal Belirleyiciler, Suç Fırsatları ve Rutin Faaliyetler Teorisi (Crime as a Function of Opportunity: Situational Determinants of Crime, Crime Opportunities and Routine Activities Theory). Polis Bilimleri Dergisi: 11 (2), 1-29.

Dolu, O., Uludağ, Ş. \& Doğutaş, C. (2010). Suç Korkusu: Nedenleri, Sonuçları ve Güvenlik Politikaları İlişkisi (Fear of Crime: Causes, Consequences, and its Relation with Justice Policy). Ankara Üniversitesi SBF Dergisi, 65 (1), 57-81.

Fernandez, M. (2005). Crime Prevention and The Perception of Safety in Campus Design, Submitted to the Graduate Faculty of the Louisiana State University and Agricultural and Mechanical College in partial fulfillment of the requirements for the degree of Master of Landscape Architecture, Louisiana State University.

Ferraro, K. (1995). The Fear of Crime: Interpreting Victimization Risk, New York: State University of New York Press.

Fisher, B. S. (1995). Crime and Fear on Campus. The Annals of the American Academy of Political and Social Science. Vol. 539, 85-100.

Kaminski, R.J., Koons-Witt, B.A., Thompson, N.S., Weiss, D. (2010). The Impacts of the Virginia Tech and Northern Illinois University shootings on fear of crime on campus. Journal of Criminal Justice. DOI: 10.1016/j.jcrimjus.2009.11.011. 38 (2010) 88-98.

Karakaya, O. (2015). Liseli Gençlerde Suç Mağduru Olma Korkusu: Ankara Örneği (Fear of Crime among High School Youth: A Case of Ankara). Hacettepe Üniversitesi Sosyal Bilimler Enstitüsü Sosyoloji Anabilim Dalı, Yüksek Lisans Tezi, Ankara.

Kul, M. 2013. Suçtan Daha Büyük Suç Korkusu İstanbul'da Bir Alan Araştırması. İstanbul: Yeniyüzyıl.

Kula, S., Çakar, B. (2015). Maslow İhtiyaçlar Hiyerarşisi Bağlamında Toplumda Bireylerin Güvenlik Algısı ve Yaşam Doyumu Arasındaki İlişki (The Relationship between Perceived Life Satisfaction and Safety of People in Society within the Frame of Maslow's Hierarchical Needs). Bartın Üniversitesi İ.İ.B.D ,6(12),191-210.

McConnell, E. H. (1997). Fear of Crime on Campus: A Study of a Southern University. Journal of Security Administration, 20, 22-46.

McCreedy, K.R., Dennis, B.G. (1996). Sex-Related Offenses and Fear of Crime on Campus. Journal of Contemporary Criminal Justice 12, 69-80.

Newman, O. (1973). Defensible Space: Crime Prevention Through Urban Design, New York: The Macmillan Publication Company, p. 264.

Özaşçılar M. (2015). Suç Korkusu ve Yakın Çevre Düzensizliği İlişkisi: Kırık Cam Teorisi, Editörler: Âdem Solak, Öner Solak, Gündelik Hayat Sosyolojisi Açısından Suç ve Suç Korkusu. Ankara: Hegem Vakfı Yayınları.

Özaşçılar, M., Ziyalar, N. (2009). Suç Korkusu: İstanbul'da Yaşayan 18-25 Yaş Grubu Üniversite Öğrencilerin Mağdur Olma Riskleri Hakkındaki Görüşlerin Değerlendirilmesi (Fear of Crime: The Evaluation of University Students' Who Live in Istanbul, Aged Between 18 to 25; Perception of Victimization Risks). Adli Bilimler Dergisi, 8 (1), 7-17.

Öztürk, M. (2015). Medya ve Suç Korkusu Arasındaki İlişki (A Relationship Between Media and Fear Of Crime). International Journal of Social Science, 36, 251-263.

Schuetz, P. (2005). UCLA Community College Review: Campus Environment: A Missing Link in Studies of Community College Attrition. Community College Review, 32(4), 60-80.

Sipahi, E. B. (2017). Üniversiteli Kız Öğrencilerin Suç Korkularına "Toplumsal Kaygı" Perspektifinden Bakmak: Konya Örneğinde Bir Alan Araştırması (Considering The Female University Students' Fear of Crime from "The Community Concern Perspective": A Case Study In Konya). Karadeniz Sosyal Bilimler Dergisi, Kadın Özel Sayısı 9(9), 383-400.

Strange, C. C., \& Banning, J. H. (2001). Educating by Design: Creating Campus Learning Environments That Work. San Francisco: Jossey-Bass.

URL-1, (2019). CSS Campus Safety and Security, https://ope.ed.gov/campussafety/\#/, (accessed in: 17.02.2019), (In English). 
URL-2, (2019). Üniversitelerde Güvenlik Önlemleri Dışarıdan Başlamalı, https://www.haberler.com/universitelerde-guvenlik-onlemleri-disaridan-11647431haberi/, (accessed in:29.07.2019), (In Turkish).

URL-3, (2018). Selçuk Üniversitesi resmî web sayfası, http://www.selcuk.edu.tr/\#, (accessed in: 17.07.2018), (In Turkish).

URL-4 (2016). The Handbook for Campus Safety and Security Reporting, https://www2.ed.gov/admins/lead/safety/handbook.pdf, (accessed in:10.07.2018), (In English).

URL-5, (2018). 2017-2018 Eğitim-Öğretim Yılı Öğrenci İstatistikleri, http://www.selcuk.edu.tr/dosyalar/files/102/1\%20Genel\%20\%C3\%96\%C4\%9Frenci\%20 Say\%C4\%B1lar\%C4\%B1\%20(Konya\%20Merkez\%20ve\%20\%C4\%B0I\%C3\%A7eler)\%20. pdf, (Accessed in: 17.07.2018), (In Turkish).

Van Dijk, J.J.M., Mayhew, P. \& Killias, M. (1990). Experiences of crime across the world: Key findings from the 1989 International Crime Survey. Deventer: Kluwer Law and Taxation.

Waters, J., Neale, R.H. ve Mears, K. (2005). Perceptions of personal safety in relation to the physical environment of university campuses, CIB Joint Symposium on Advancing Facilities Management and Construction through Innovation, June 13-16 2005, 230-242, Helsinki.

White, G. (2019). Campus Community's Perception of Victimization and Fear of Crime Regarding Campus Violence and Safety. In The Graduate School, Eastern Illınoıs Unıversıty Masters Theses. Charleston, Illınoıs.

Warr, M. (2000). Fear of Crime in the United States: Avenues For Research and Policy. Criminal Justice 2000: Measurement and Analysis of Crime and Justice, 4, 451-489.

Woolnough, D.A. (2009). Fear Of Crime on Campus: Gender Differences in Use of SelfProtective Behaviours at an Urban University. Security Journal, 22(1), 40-55.

\section{EXTENDED ABSTRACT}

The purpose of the present study was to determine the perceptions of the students on fear of crime regarding the physical characteristics of Alaeddin Keykubad Campus. The student's fear of crime regarding the physical environment of Alaeddin Keykubad Campus was determined in the present study according to quantitative (questionnaires) and qualitative (participant observation and perceptual evaluation) questioning methods. The study field was Selcuk University, Alaeddin Keykubad Campus. A total of 77.783 associate degree, undergraduate and graduate-degree students who were studying at Selcuk University, Alaeddin Keykubad Campus, constituted the universe of the study. Since it was impossible to reach the entire universe, time was considered as a limiting factor, and the questionnaires were conducted between 1-30 June 2018. The data obtained in these questionnaires were evaluated in line with the feedbacks of 225 students (sampling of the study).

A total of $64.9 \%$ of the 225 students, who answered the questionnaires, were female, and $35.1 \%$ were male. The higher participation of the female students compared to the male students suggests that female students are more sensitive and anxious about fear of crime, because students answered the questionnaires voluntarily.

A total of $44.9 \%$ of the students perceived campus as a safe place during the day; $34.7 \%$ said they perceived it as a safe place, and sometimes unsafe at night. According to gender and perception of security in campus according to day and night difference, $66.9 \%$ of the female students and $71.2 \%$ of the male students defined the campus as a safe place during the day; $46.7 \%$ of the female students and $59.5 \%$ of the male students considered it to be a safe place at night. According to this result, it can be argued that the female students feel less safe compared to male students, which means that they are more concerned about being the victim of a crime.

Among the places that made the participants feel unsafe in the campus included crowded places, neglected and ruined areas, and entry and exit points as the top 3 unsafe places. Crowded places were perceived as unsafe because of unknown outsiders coming from outside the campus; neglected and ruined areas were perceived as unsafe because of causing anxiety 
and worry due to spatial irregularities; and entry and exit points were perceived as unsafe because of lack of control.

A total of $57.8 \%$ of the students who participated in the study said that they were never worried about crime in the campus, while $42.2 \%$ said that they were rarely concerned. Sometimes people try to hide and not express their fear and concerns. For this reason, there is a high probability that the real answer to this question was not given. A total of $64.4 \%$ of the female students, and $45.6 \%$ of the male students said that they were concerned about crime in the campus. This result may not reflect the real condition because especially males tend to hide their fear, and the rates of concerns of male students about crime might be greater.

There was a statistically significant relation between gender and fear of crime, and the direction of the relation was negative. A total of $78 \%$ of the female students, and $62.5 \%$ of the male students said that they felt unsafe because of fear of crime. According to these results, it was determined that the female students had more fear of crime than male students.

To the question "Have you been exposed to crime in campus?", $85.8 \%$ of the students said "No", and $14.2 \%$ said "Yes". Out of the 32 students who were exposed to crime in the campus, 23 were exposed to verbal assault, 3 were exposed to physical assault, 2 were exposed to sexual assault, 2 were threatened, and 2 were exposed to theft. These results may not reflect the reality. Especially sexual assault can be kept as a secret because it is not something people can express easily. For this reason, sexual assault rates might be actually higher.

The fear of crime and being exposed to crime is directly related to the area where people are in, and shows the consequences of how people perceive and evaluate these areas. The areas that are used extensively in the campus (i.e. library, cafeteria, Rainbow, Suleyman Demirel Cultural Center, and surrounding areas of educational buildings, tramway stops) do not affect the fear of crime of students in a negative way. Uncontrolled access to the campus always causes fear. The nearby surroundings of the educational buildings were determined to be among the areas far from the fear of being exposed to crime parallel to the intense use of the area by the students.

The landscape of Alaeddin Keykubad Campus, which changed and transformed in time, must be dealt with considering the concerns of students and academic and administrative staff regarding the fear of crime and safety. The same study can be conducted on academic and administrative staff. In this way, it will be more effective to produce solutions by understanding the safety perceptions and fear of crime of all users in the campus.

Students, and academic and administrative staff should be informed by creating a Campus Security Guide. This guide will be very effective, especially for new students who will experience the life in Alaeddin Keykubad Campus for the first time, and for academic and administrative staff, who newly start their duties. The following items should be included in the "Alaeddin Keykubad Campus Security Guide" of Selcuk University:

- Information on the boundaries of the campus, its physical environment, and alternative means of transportation,

- Information on academic and administrative units and their locations in the campus,

- Explanation of the rules to be followed in the campus (i.e. traffic rules, indoor and outdoor rules),

- Explanation of special events (i.e. fog, wild animals, stray dogs, foreign people) to be careful in the campus,

- Information on the unsafe areas in the campus (i.e. woodland areas surrounding the campus, being more careful in dark and dim areas),

- Information on threats, risks and types of crime and statistics in the campus,

- Students, and academic and administrative staff must be explained to comply with the rules and warnings to ensure their own individual safety,

- Information must be given on the person and numbers to be called or reached in case of an emergency. 